\title{
Influence of Fucoidan Extracts from Different Fucus Species on Adult Stem Cells and Molecular Mediators in In Vitro Models for Bone Formation and Vascularization
}

\author{
Fanlu Wang ${ }^{1}$, Yuejun Xiao ${ }^{1}$, Sandesh Neupane ${ }^{2,+}{ }^{\mathbb{D}}$, Signe Helle Ptak ${ }^{3,+}$, Ramona Römer ${ }^{1}$, Junyu Xiong ${ }^{1}$, \\ Julia Ohmes ${ }^{1}$, Andreas Seekamp ${ }^{1}$, Xavier Fretté ${ }^{3}$, Susanne Alban ${ }^{2} \mathbb{D}$ and Sabine Fuchs ${ }^{1, *}$
}

1 Experimental Trauma Surgery, Department of Orthopedics and Trauma Surgery, University Medical Center Schleswig-Holstein, 24105 Kiel, Germany; fanluwang@gmail.com (F.W.); xiao_yuejun@163.com (Y.X.); ramona.roemer@googlemail.com (R.R.); serene.xj@gmail.com (J.X.); Julia.Ohmes@uksh.de (J.O.); Andreas.Seekamp@uksh.de (A.S.)

2 Department of Pharmaceutical Biology, Pharmaceutical Institute, Kiel University, 24148 Kiel, Germany; sneupane@pharmazie.uni-kiel.de (S.N.); salban@pharmazie.uni-kiel.de (S.A.)

3 SDU Chemical Engineering, University of Southern Denmark, 5230 Odense, Denmark; sihp@igt.sdu.dk (S.H.P.); xavier.frette@gmail.com (X.F.)

* Correspondence: Sabine.Fuchs@uksh.de; Tel.: +49-431-500-24561

+ Equally contributed.

\section{check for} updates

Citation: Wang, F.; Xiao, Y.; Neupane, S.; Ptak, S.H.; Römer, R.; Xiong, J.; Ohmes, J.; Seekamp, A.; Fretté, X.; Alban, S.; et al. Influence of Fucoidan Extracts from Different Fucus Species on Adult Stem Cells and Molecular Mediators in In Vitro Models for Bone Formation and Vascularization. Mar. Drugs 2021, 19, 194. https://doi.org/ $10.3390 /$ md19040194

Academic Editor: Donghwa Kim

Received: 15 March 2021

Accepted: 26 March 2021

Published: 29 March 2021

Publisher's Note: MDPI stays neutral with regard to jurisdictional claims in published maps and institutional affiliations.

Copyright: (C) 2021 by the authors Licensee MDPI, Basel, Switzerland. This article is an open access article distributed under the terms and conditions of the Creative Commons Attribution (CC BY) license (https:// creativecommons.org/licenses/by/ $4.0 /)$.

\begin{abstract}
Fucoidans, sulfated polysaccharides extracted from brown algae, are marine products with the potential to modulate bone formation and vascularization processes. The bioactivity and safety of fucoidans are highly associated with their chemical structure, which may vary with algae species and extraction method. Thus, in depth evaluation of fucoidan extracts in terms of endotoxin content, cytotoxicity, and their detailed molecular biological impact on the individual cell types in bone is needed. In this study, we characterized fucoidan extracts from three different Fucus species including Fucus vesiculosus (Fv), Fucus serratus (Fs), and Fucus distichus subsp. evanescens (Fe) for their chemical features, endotoxin content, cytotoxicity, and bioactive effects on human outgrowth endothelial cells (OEC) and human mesenchymal stem cells (MSC) as in vitro models for bone function and vascularization. Extracts contained mainly high molecular weight (HMW) fucoidans and were free of endotoxins that may cause inflammation or influence vascularization. OEC tolerated fucoidan concentrations up to $200 \mu \mathrm{g} / \mathrm{mL}$, and no indication of cytotoxicity was observed. The inflammatory response, however, investigated by real-time PCR (RT-PCR) and enzyme-linked immunosorbent assay (ELISA) and endothelial barrier assessed by impedance measurement differed for the individual extracts. MSC in comparison with endothelial cells were more sensitive to fucoidans and showed partly reduced metabolic activity and proliferation at higher doses of fucoidans. Further results for MSC indicated impaired osteogenic functions in alkaline phosphatase and calcification assays. All tested extracts consistently lowered important molecular mediators involved in angiogenesis, such a VEGF (vascular endothelial growth factor), ANG-1 (angiopoietin 1), and ANG-2 (angiopoietin 2), as indicated by RT-PCR and ELISA. This was associated with antiangiogenic effects at the functional level using selected extracts in co-culture models to mimic bone vascularization processes during bone regeneration or osteosarcoma.
\end{abstract}

Keywords: fucoidan; mesenchymal stem cells (MSC); outgrowth endothelial cells (OEC); angiogenesis; bone vascularization

\section{Introduction}

Fucoidans, sulfated polysaccharides derived from brown algae, have been reported to influence a series of physiological key processes such as inflammation [1-3], vascularization [4,5], as well as the recruitment of stem cells [6]. All these mentioned biological processes play a fundamental role for a variety of different tissues or diseases and are of 
particular interest for applications in bone health, ranging from the maintenance of functional bone tissue and enhancement of bone regeneration and repair, up to the treatment of bone tumors, such as osteosarcoma [7-9].

In most cases, extracts comprise a heterogeneous composition with large variations in monosaccharide composition, molecular weight, sulfation degree, etc. [10,11]. Accordingly, the structure-function relationship for fucoidans often remains unclear, thus limiting their suitability as a biomedical compound. One key prerequisite for using fucoidans in biomedical applications is to develop purified and standardized extracts with well-defined chemical characteristics [12]. In addition to the production of extracts with distinct physical or chemical properties, the evaluation of the tissue- or cell type-specific effects is an important strategy to ensure biological safety by selecting non-toxic but bio-functional doses $[13,14]$. Further, tests of fucoidans in selected cell models providing controlled physiological conditions can contribute to a better understanding of how fucoidans modulate processes, such as bone formation or vascularization. In addition, such tests enable identification of the associated molecular mediators influenced by fucoidan extracts. In previous reports, we have demonstrated biological effects in in vitro models for bone and associated vascularization processes using a crude fucoidan extract from Fucus vesiculosus [4] or fractionated extracts from Fucus distichus subsp. evanescence [15]. Before biomedical use of fucoidans, complex testing procedures are necessary. This is a challenging task, especially when considering the large number of extracts that can be gained from the different species of brown algae, as well as from different extraction methods or processing technologies, such as fractionation [10,16,17]. In this context, a detailed characterization of the molecular biological effects of fucoidans in the target cells will support the selection of extracts with the best biomedical effect for the envisioned therapeutic aim, contribute to their biological safety, and enable definition of structural and functional relationships at cellular and molecular levels.

In this study, using a variety of characterization methods in in vitro models, we prepared and tested fucoidan extracts from different Fucus species and compared them in terms of their chemical characteristics, endotoxin content, and their biological impact on endothelial cells and bone-forming mesenchymal stem cells.

\section{Results}

\subsection{Chemical Characterization of Fucoidan Extracts}

Analysis of the monosaccharide composition by acetylation analysis of the six fucoidans from F. vesiculosus (Fv), F. distichus subsp. Evanescens (Fe), and Fucus serratus (Fs) revealed that $\mathrm{Fv} 3, \mathrm{Fe}$, and $\mathrm{Fs} 1$ had the highest fucose content (above $75 \%$ ) along with the highest degrees of sulfation (DS), whereas the other three extracts had a fucose content below $60 \%$. In addition, Fv1 and Fs2 contained a considerable amount of glucose (Table 1), which probably represents co-extracted $\mathrm{B}-1,3$-glucans of brown algae.

The molecular mass (MW) of the fucoidans largely differed from $84 \mathrm{kDa}(\mathrm{Fe})$ to $730 \mathrm{kDa}$ (Fv2). The MW and size parameter of the samples are summarized in Table 1. Further, the MW distribution plots of the fucoidans and MW ranges of three weight fractions $(\leq 20 \%$, $20-80 \%, \geq 80 \%(\mathrm{~m} / \mathrm{m})$ ) of different fucoidans are included as Supplementary Materials (Table S1, Figures S1 and S2). These data illustrate that all the fucoidans extracts represent highly polydisperse mixtures; even the MW of Fe with the lowest polydispersity ranged from $22 \mathrm{kDa}$ to $403 \mathrm{kDa}$. 
Table 1. Composition of neutral monosaccharides (Fuc (fucose), Xyl (xylose) Gal, (galactose), Glc (glucose)), degree of sulfation (DS), protein content, molecular mass, and rms radius of the extracted fucoidans from fucus vesiculosus (Fv), fucus distichus subsp. evanescens (Fe)and fucus serratus (Fs)

\begin{tabular}{|c|c|c|c|c|c|c|c|c|}
\hline \multicolumn{5}{|c|}{$\begin{array}{c}\text { Monosaccharide } \\
\text { Composition }(\mathrm{mol} \%)^{a}\end{array}$} & \multirow{2}{*}{$\begin{array}{c}\text { Degree of } \\
\text { Sulfation }{ }^{b} \text { DS }\end{array}$} & \multirow{2}{*}{$\begin{array}{c}\text { Protein } \\
\text { Content }^{\mathrm{c}}(\%)\end{array}$} & \multirow{2}{*}{$\begin{array}{l}\text { Mw } \\
(\mathrm{kDa})\end{array}$} & \multirow{2}{*}{$\begin{array}{c}\text { Rms Radius } \\
\text { (nm) }\end{array}$} \\
\hline & Fuc & Xyl & Gal & Glc & & & & \\
\hline Fv1 & 50.2 & 9.5 & 7.9 & 27.7 & 0.28 & 1.88 & 449 & 35 \\
\hline Fv2 & 57.7 & 18.5 & 13.2 & 2.9 & 0.26 & 1.08 & 730 & 33 \\
\hline Fv3 & 81.4 & 8.5 & 6.3 & 0.7 & 0.35 & 0.33 & 173 & 24 \\
\hline $\mathrm{Fe}$ & 76.7 & 9.8 & 5.7 & 0.0 & 0.41 & 2.18 & 84 & 21 \\
\hline Fs1 & 76.2 & 6.5 & 3.3 & 11.2 & 0.61 & 0.52 & 272 & 41 \\
\hline Fs2 & 56.1 & 4.1 & 5.0 & 32.6 & 0.32 & 0.51 & 172 & 36 \\
\hline
\end{tabular}

a Determined according to the method of Blakeney et al. [18]. ${ }^{\mathrm{b}}$ Averaged number of sulfate groups per monosaccharide, calculated as $-\mathrm{SO}_{3} \mathrm{Na}$ residues from sulfur content determined by elemental analysis. ${ }^{\mathrm{c}}$ The content of protein was calculated by elemental analysis (nitrogen (\%)).

\subsection{Endotoxicity}

Before characterizing the cytotoxicity and biological activity, the endotoxin content in the extracts was determined by EndoLISA to exclude influences by endotoxins that might further cause endothelial cell activation and severe inflammatory responses. As depicted in Table 2, endotoxin levels were below critical values for all tested extracts in this study.

Table 2. Endotoxicity of fucoidan extracts and heparin determined by EndoLISA ${ }^{\circledR}$ kit.

\begin{tabular}{ccc}
\hline Fucoidan Extracts/Heparin & Shortage & Endotoxicity (EU/mL) \\
\hline Heparin (for physico-chemical analysis, Y0001282) & Hep. & 0.0778 \\
Fucoidan from Fucus vesiculosus crude (Fvc, Sigma, F5631-1G) & Fvc & 0.0746 \\
Fucoidan from Fucus vesiculosus pure (Fvp,Sigma, F8190) & Fvp & 0.0750 \\
Fv_KF_7-7-2017_SDU_24H_M1-0.1-HCL-22C_frac1 & Fv1 & 0.0059 \\
Fv_KF_10-10-17_SDU_24H_M1-22C_frac3 & Fv2 & 0.0206 \\
Fv_KF_170707_SDU_180405_M313D0.2 & Fv3 & 0.0743 \\
Fs_KF_171010_SDU_180501_M342D0.2 & Fs1 & 0.0743 \\
Fs_KF_171010_SDU_180405_M331D0.2 & Fs2 & 0.0743 \\
Fe_KF_170707_SDU_180405_M313D0.2 & Fe & 0.0732 \\
\hline
\end{tabular}

\subsection{Effect of Fucus Extracts on Metabolic Activity and Cytotoxicity in Endothelial Cells}

Independent from Fucus species and the tested concentration ( 1 to $200 \mu \mathrm{g} / \mathrm{mL})$ (Figure 1), no cytotoxic effects were observed for tested extracts in human microvascular endothelial cells from the peripheral blood (OEC). Using lactate dehydrogenase (LDH) assessment as an indicator for cell membrane damage, all the tested extracts resulted in reduced LDH levels observed at both investigated time points ( $72 \mathrm{~h}, 168 \mathrm{~h})$. Remarkably, in contrast to the other test compounds and to the results on day 7, Fv1 and Fv2, the two fucoidans with the highest MW but lowest DS, significantly improved the metabolic activity on day 3. In agreement with the test principles of MTS and LDH, assay data resulted in complementary results for metabolic activity and cytotoxicity.

\subsection{Impact of Fucus Extracts on the Endothelial Barrier}

Morphological assessment of OEC by immunofluorescence for VE-cadherin after seven days of treatment $(100 \mu \mathrm{g} / \mathrm{mL})$ indicated partly a rearrangement of the cell layer and the endothelial cell-cell contact mediated barrier. This effect was most prominent for the commercially available crude fucoidan from Fucus vesiculosus (Figure 2). Morphological assessment further indicated to some extent effects on the cell-cell contacts for other Fucus vesiculosus extracts (Figure 2, arrow); these, however, were much less evident. 
a)

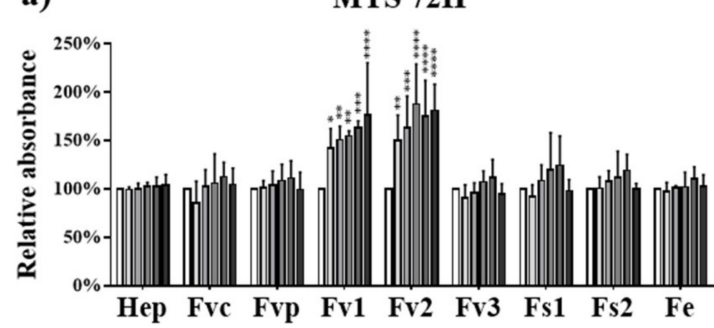

b)

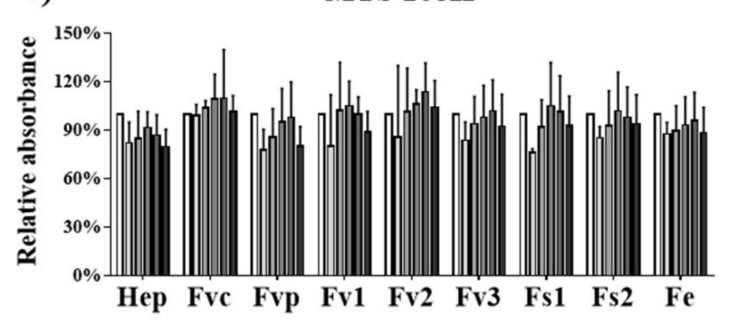

c)

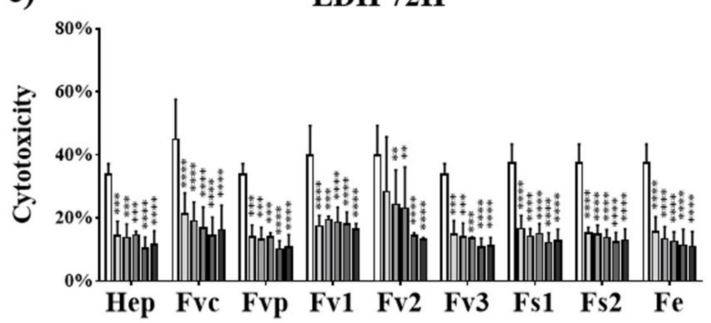

d)

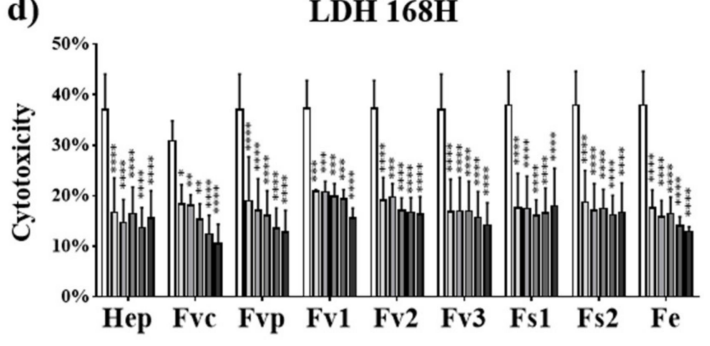

$\square$ Control $\square 1 \mu \mathrm{g} / \mathrm{mL} \quad \square 10 \mu \mathrm{g} / \mathrm{mL}$

$50 \mu \mathrm{g} / \mathrm{mL}$

$100 \mu \mathrm{g} / \mathrm{mL}$

$200 \mu \mathrm{g} / \mathrm{mL}$

Figure 1. Cell metabolic activity of outgrowth endothelial cells (OECs) determined by MTS assay at (a) $72 \mathrm{~h}$ and (b) $168 \mathrm{~h}$ and cytotoxicity for OECs determined by lactate dehydrogenase (LDH) at (c) $72 \mathrm{~h}$ and (d) $168 \mathrm{~h}$ after treated with fucoidan extracts and heparin at different concentrations of 1, 10, 50, 100, and $200 \mu \mathrm{g} / \mathrm{mL}$. Two-way ANOVA, ${ }^{*} p<0.05,{ }^{* *} p<0.01$, *** $p<0.001, * * * * 0<0.0001, n=3$.

To quantify potential effects of the tested fucoidans on the endothelial barrier, we performed electric impedance measurements using an electrical cell-substrate impedance sensing (ECIS) system (Figure 3). For this, OEC were grown until the impedance reached a stable level as an indicator of a stable and tight endothelial cell layer. Then, OEC were treated with the fucoidan extracts for a further seven days. Depicted impedance values were normalized to measured values on day $0(100 \%)$. In accordance with the morphological observation in Figure 2, treatment with the crude fucoidan from Fucus vesiculosus resulted in a significant reduction of the impedance on day 5. A similar effect was observed for Fv1 and Fv2, although here the reduction of the impedance showed only a tentative trend. In contrast, the barrier of OEC after treatment with Fs1, Fs2, and Fe remained stable, and no impedance reduction was observed.

\subsection{Effects of Fucus Extracts on Endothelial Activation and Inflammation}

To study the impact of fucoidan extracts $(100 \mu \mathrm{g} / \mathrm{mL})$ on inflammatory and angiogenic endothelial cell activation $[19,20]$, the secretion of associated inflammatory mediators (interleukin-6 IL-6 and intracellular adhesion molecule-1(ICAM-1)) and the proangiogenic molecule ANG-2 produced by endothelial cells [21] was determined by ELISA (Figure 4a-c). In addition, we performed real-time PCR for gene expression of IL-6, ICAM-1, and vascular cells adhesion molecule-1 (VCAM-1) (Figure S3) but we focus here on the protein level due to the higher physiological relevance. For protein assessment, all samples were harvested after seven days. Only Fv2 treatment resulted in a significant increase of IL-6 compared with the control, indicating an inflammatory reaction of the endothelial cells by Fv2, which was further underlined by a tentative increase in soluble ICAM-1. A similar but not significant increase of IL-6 was observed for Fv1. Further, the results indicate a significant reduction of angiopoietin 2 (ANG-2) for most extracts except for Fvp and Fe, indicating a reduction of this proangiogenic molecule produced by endothelial cells. 

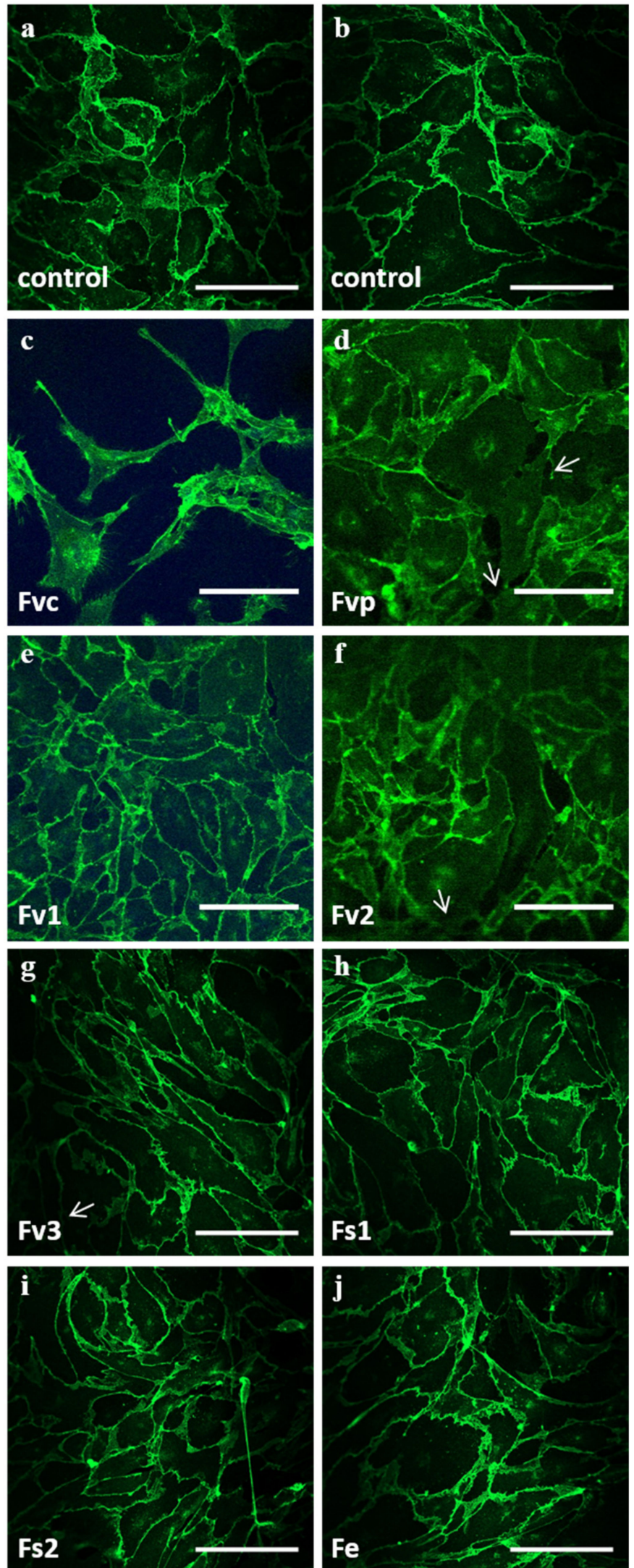

Figure 2. Confocal laser scanning microscopy of OEC mono-cultures on day 7 for $(\mathbf{a}, \mathbf{b})$ controls and treatment of $100 \mu \mathrm{g} / \mathrm{mL}$ fucoidan extracts: (c) Fvc, (d) Fvp, (e) Fv1, (f) Fv2, (g) Fv3, (h) Fs1, (i) Fs2 and (j) Fe. VE-cadherin is depicted in green. The scale bar represents $100 \mu \mathrm{m}$. 


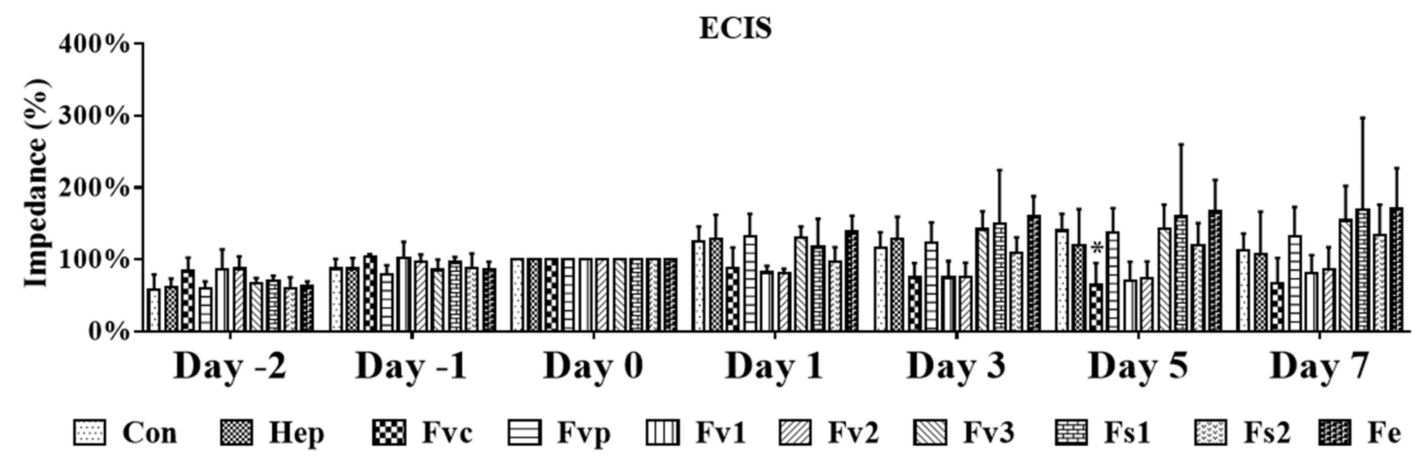

Figure 3. Cell barrier characterized by electrical cell-substrate impedance sensing (ECIS) for OEC mono-culture in response to fucoidan and heparin at $100 \mu \mathrm{g} / \mathrm{mL}$ treatment. Two-way ANOVA, ${ }^{*} p<0.05, n=3$.

a)

Elisa IL-6

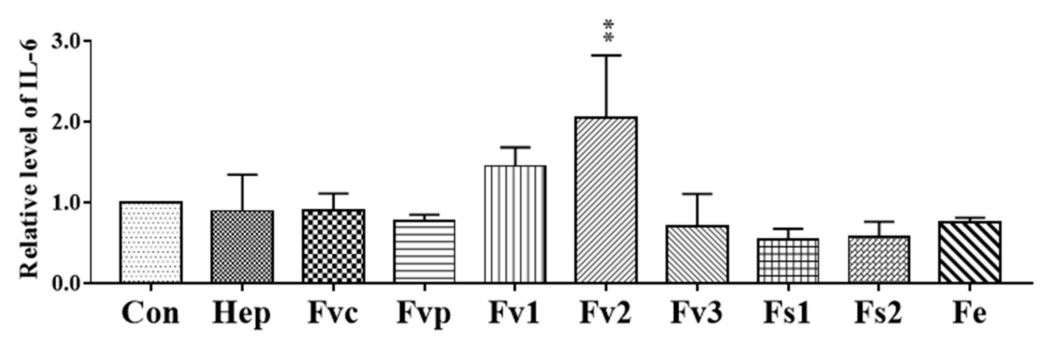

b)

Elisa ICAM-1

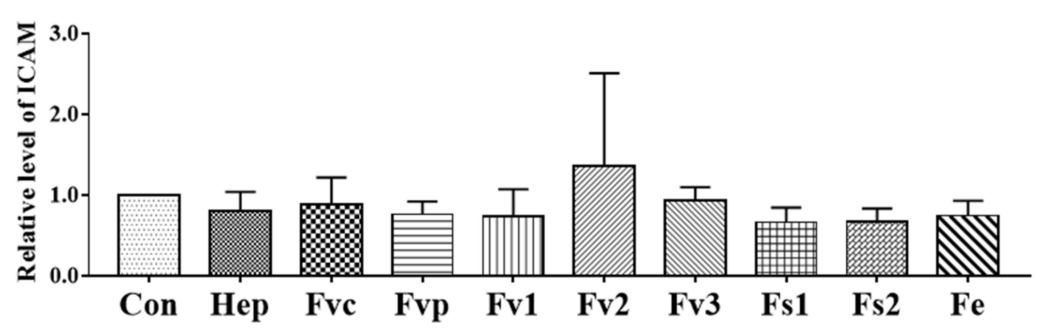

c)

Elisa ANG-2

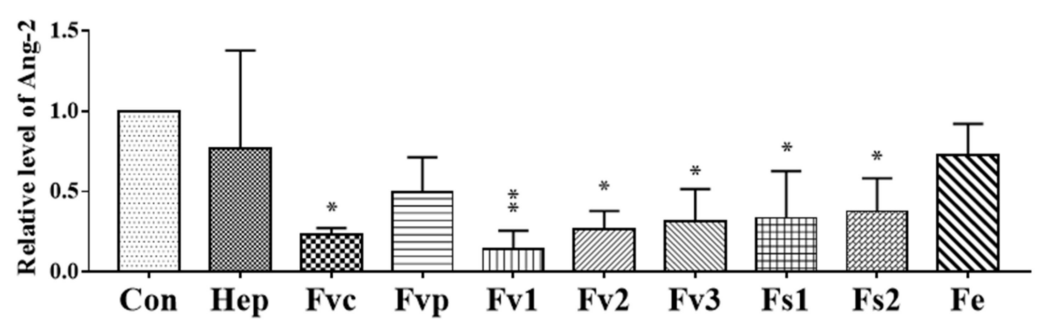

Figure 4. The protein level of inflammatory molecules (a) IL-6, (b) soluble ICAM-1 and (c) angiopoietin 2 (ANG-2) in the supernatant determined by ELISA for OEC treated with $100 \mu \mathrm{g} / \mathrm{mL}$ fucoidan. One-way ANOVA, ${ }^{*} p<0.05,{ }^{* *} p<0.01$, $n=3$. 


\subsection{Effect of Fucus Extracts on Metabolic Activity and Cytotoxicity in Human Mesenchymal Stem Cells}

The effects of Fucus extracts on the metabolic activity and cytotoxicity for MSCs were tested using concentrations from 1 up to $200 \mu \mathrm{g} / \mathrm{mL}$. In contrast to the results for endothelial cells, treatment with Fvc, Fvp, Fv1, Fv2, and Fv3 at concentrations higher than $10 \mu \mathrm{g} / \mathrm{mL}$ reduced the metabolic activity of MSC at both investigated time points (Figure $5 \mathrm{a}, \mathrm{b}$ ). For treatment with Fs1, only high concentrations of 100 and $200 \mu \mathrm{g} / \mathrm{mL}$ indicated a reduced metabolic activity after three days of incubation, while Fs2 and Fe extracts had no negative influence on the metabolic activity of MSC. Because LDH values as an indicator of membrane integrity (Figure $5 c, d$ ) were not significantly decreased, we assume that the decreased values in the MTS assay refer to a decrease in metabolic activity or proliferation rather than a cytotoxic effect.

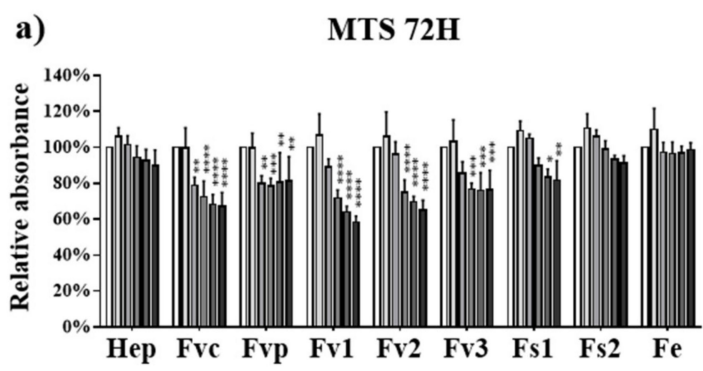

c)

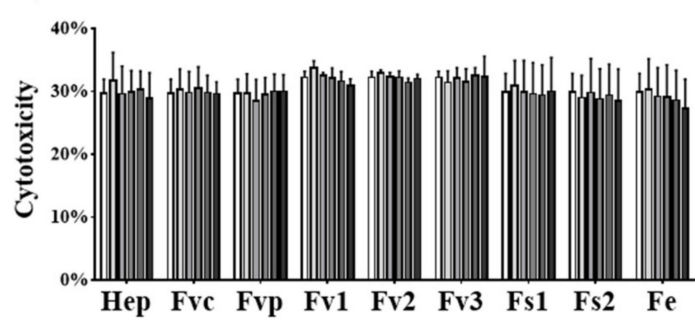

d)

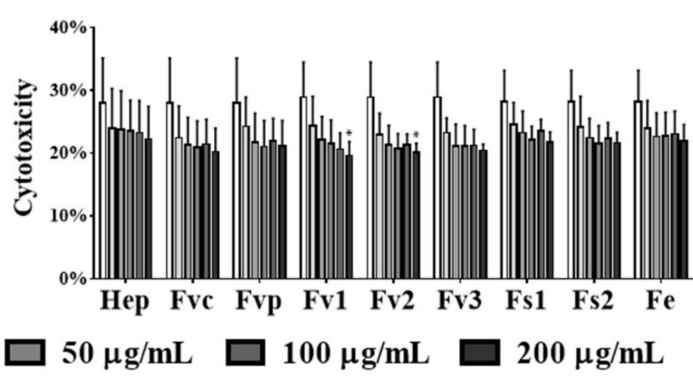

Figure 5. Cell metabolic activity of mesenchymal stem cells (MSCs) determined by MTS assay at (a) $72 \mathrm{~h} \mathrm{and} \mathrm{(b)} 168 \mathrm{~h}$ and cytotoxicity for MSCs determined by LDH at (c) $72 \mathrm{~h}$ and (d) $168 \mathrm{~h}$ after treated with fucoidan extracts and heparin at different concentrations of 1, 10, 50, 100, and $200 \mu \mathrm{g} / \mathrm{mL}$. Two-way ANOVA, ${ }^{*} p<0.05,{ }^{* *} p<0.01,{ }^{* * *} p<0.001,{ }^{* * * *} p<0.0001$, $n=3$.

To clarify, whether the MTS assay results reflect only a reduction of the metabolic activity or indicated a reduced proliferation, we investigated the effects using DNA quantification as a direct indicator of cellular proliferation at a concentration of 1 and $10 \mu \mathrm{g} / \mathrm{mL}$. Results for DNA quantification at day 7 as depicted in Figure $6 \mathrm{a}, \mathrm{b}$ did not show significant effects on MSC proliferation for the lower concentrations 1 and $10 \mu \mathrm{g} / \mathrm{mL}$, although these concentrations reduced partly the metabolic activity. Nevertheless, the MSC seeding density in these experiments was relatively high, potentially interfering with the proliferation capacity by cell contact-mediated inhibition. Accordingly, we performed additional experiments using a lower cell seeding density and continuous ECIS impedance measurement over seven days, focusing on a concentration of $100 \mu \mathrm{g} / \mathrm{mL}$. As depicted in Figure $6 \mathrm{c}, \mathrm{d}$, the impedance as an indicator of cell layer confluency showed a significant reduction for all tested Fucus extracts after seven days. Thus, tested Fucus extracts impaired the MSC proliferation using a higher concentration of $100 \mu \mathrm{g} / \mathrm{mL}$ and a lower cell density. 
a)

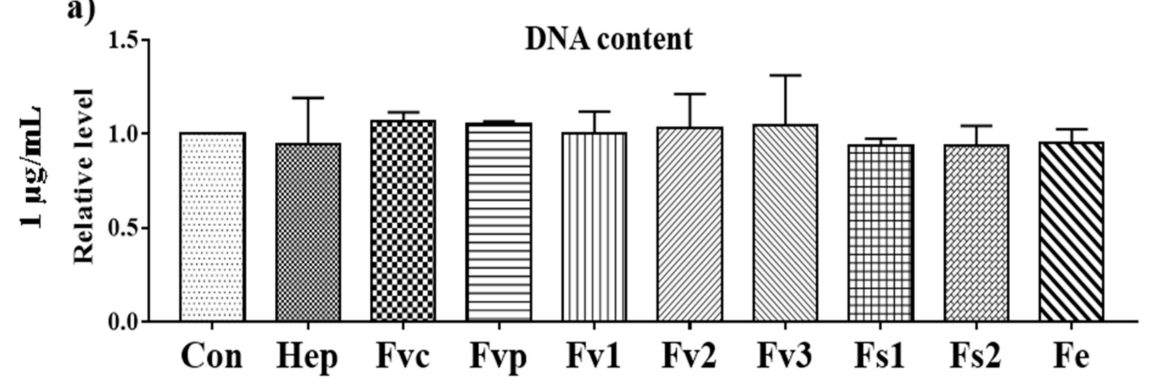

b)

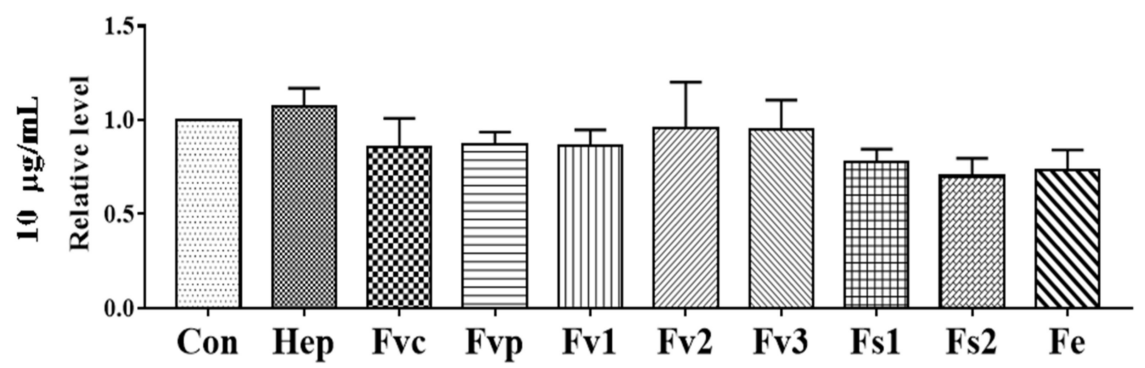

c)

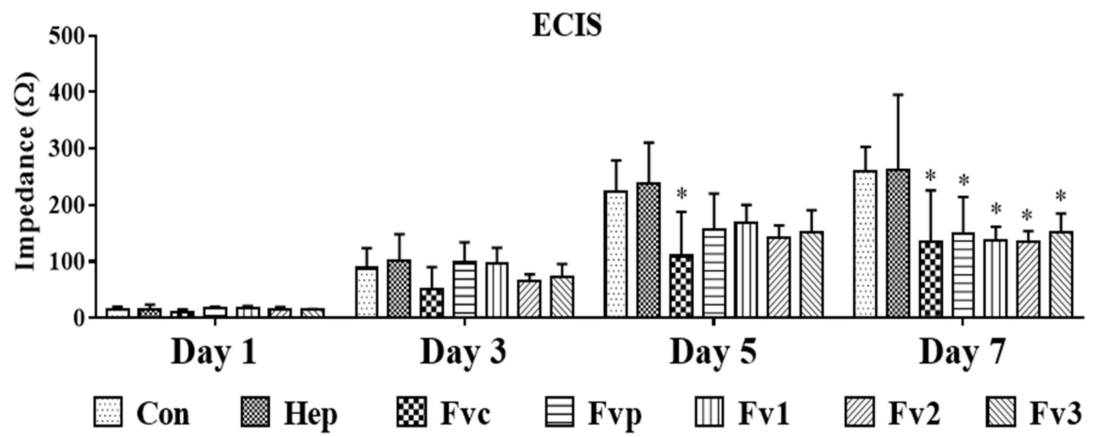

d)

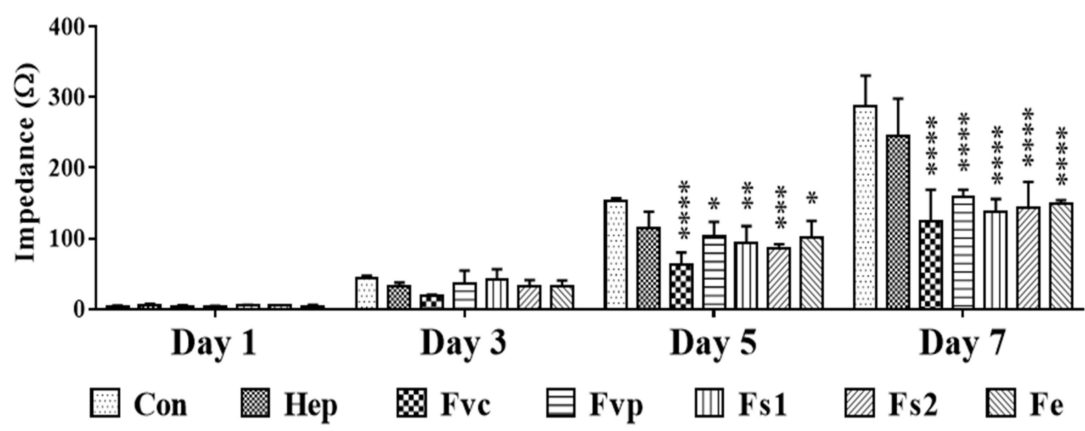

Figure 6. Effect of fucoidan on cell proliferation depicting the DNA content of MSC mono-cultures at (a) $1 \mathrm{and}(\mathbf{b}) 10 \mu \mathrm{g} / \mathrm{mL}$ fucoidan/heparin treatment and (c,d) impedance measurement for MSC (seeded at a density of $5000 \mathrm{cells} / \mathrm{cm}^{2}$ ) detected by ECIS at $100 \mu \mathrm{g} / \mathrm{mL}$ treatment. One-way ANOVA, ${ }^{*} p<0.05,{ }^{* *} p<0.01,{ }^{* * *} p<0.001,{ }^{* * * *} p<0.0001, n=3$.

\subsection{Impact of Fucus Extracts on the Osteogenic Activity in Human Mesenchymal Stem Cells}

To evaluate if Fucus extracts from different species modulate the osteogenic differentiation of MSC, we determined the expression and activity of the early osteogenic differentiation marker alkaline phosphatase and the calcification process indicating the later stages of osteogenic differentiation. The gene expression of the early osteogenic marker alkaline phosphatase (ALP) was found to be significantly downregulated on day 7 for all the fucoidan treatments except for Fs2 (Figure 7a). On day 14, the ALP activity was 
lower in fucoidan-treated cells than in the untreated group, similar to PCR data, but no significant effect was observed (Figure $7 \mathrm{~b}$ ).

a)

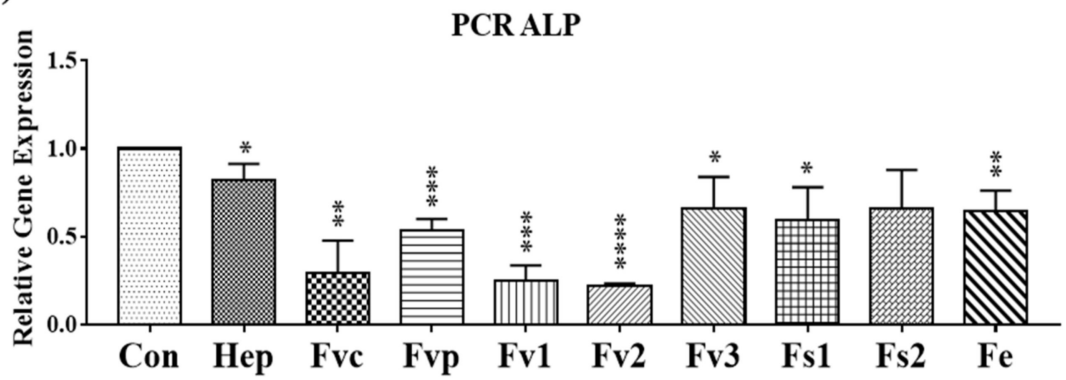

b)

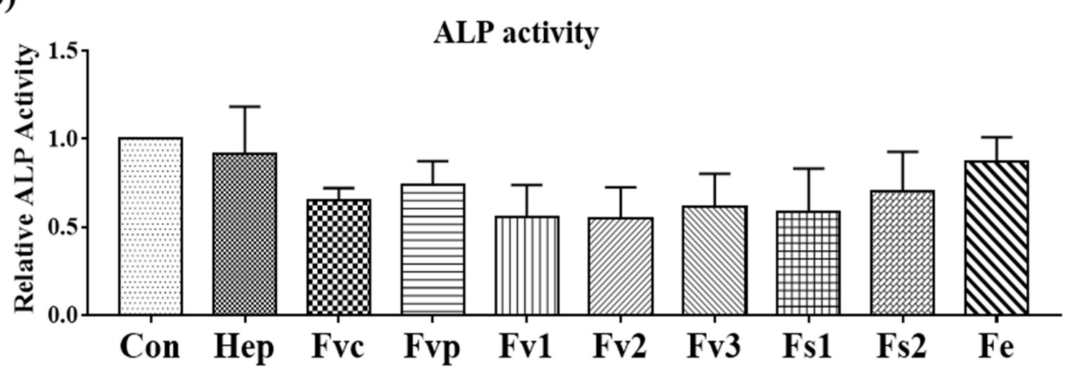

c)

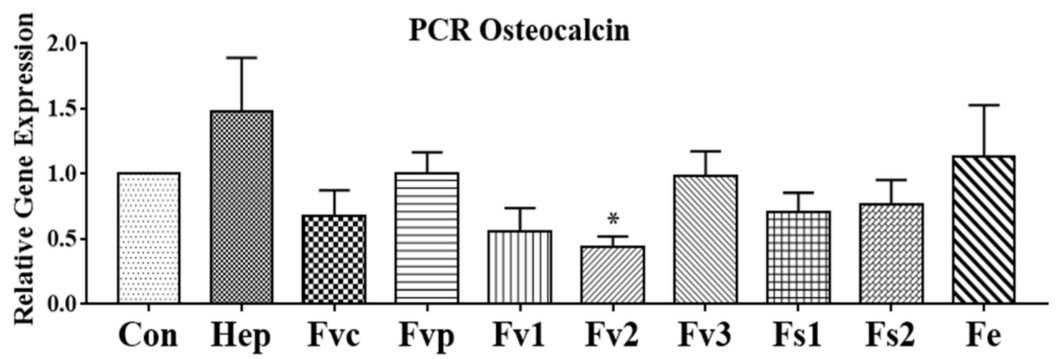

d)

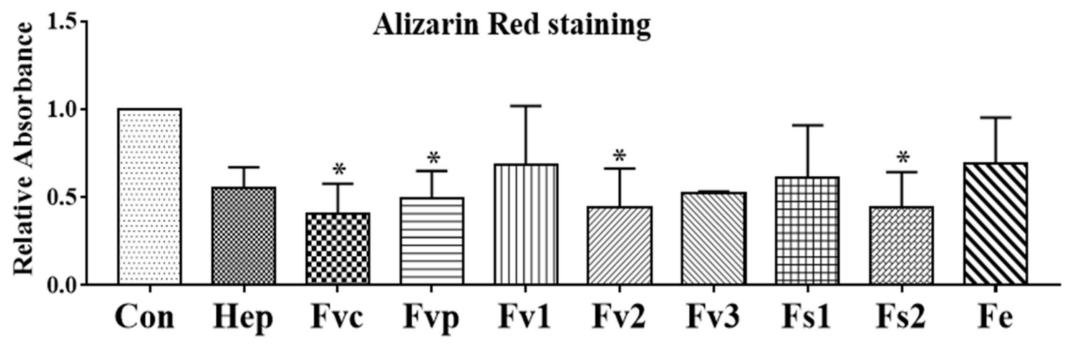

Figure 7. Relative gene expression for the osteogenic markers (a) ALP and (c) osteocalcin evaluated by semi-quantitative RT-PCR for MSC mono-cultures treated with fucoidan extracts and heparin at a concentration of $100 \mu \mathrm{g} / \mathrm{mL}$ on day 7; (b) ALP activity for the MSC mono-cultures with $100 \mu \mathrm{g} / \mathrm{mL}$ extracts treatment on day 14, and (d) the osteogenic activity determined by Alizarin Red staining for MSCs treated with $100 \mu \mathrm{g} / \mathrm{mL}$ extracts on day 14. One-way ANOVA, ${ }^{*} p<0.05,{ }^{* *} p<0.01$, *** $p<0.001,{ }^{* * * *} p<0.0001, n=3$.

As shown in Figure 7d, the calcification level determined by Alizarin Red staining showed a significant reduction when MSCs were treated with Fvc, Fvp, Fv2, and Fs2. Other extracts had a similar but not significant effect on the calcification level, and results reflected widely data by PCR for osteocalcin (Figure 7c). 


\subsection{Effects of Fucus Extracts on Regulatory Molecules for Angiogenesis in MSC}

As bioactive compounds with the potential to modulate angiogenesis in the bone, we investigated the effect of different fucoidan doses on key molecules such as vascular endothelial growth factor (VEGF) and angiopoietin 1 (ANG-1) expressed by MSC. We also studied the effect of fucoidan on stromal derived factor-1 (SDF-1), a chemokine that regulates the recruitment of various cell types including stem cells, osteoclast precursor cells, and immune-cells [22,23]. In previous studies, we found MSC to be the main producer of VEGF, SDF-1, and ANG-1 [24,25]. After fucoidan treatment, all tested extracts reduced the VEGF amount found in the supernatant of MSC (day 7). While Fvc, Fvp, Fv1, Fv2, and Fv3 caused a significant VEGF reduction at $10 \mu \mathrm{g} / \mathrm{mL}$, Fs1, Fs2, and Fe treatment already lowered VEGF levels at the lowest tested concentration of $1 \mu \mathrm{g} / \mathrm{mL}$. To achieve a significant reduction of SDF-1 levels in MSC, a concentration of $10 \mu \mathrm{g} / \mathrm{mL}$ was necessary for all tested extracts. Further, treatment with $10 \mu \mathrm{g} / \mathrm{mL}$ was necessary to reduce ANG-1 levels in MSC, with exception of Fe and Fs1, which significantly lowered ANG-1 already at the smallest tested concentration of $1 \mu \mathrm{g} / \mathrm{mL}$. Additional data regarding the gene expression for angiogenic regulator molecules in OEC and MSC are depicted in Figure S4 (supplements). Overall, the protein data suggest a clear dose-dependent effect for all tested extracts and tested target molecules for MSC, although the concentrations required to lower the levels of these growth factors slightly varied depending on the extracts or the target molecule.

\subsection{Influence of Selected Fucus Extracts on the Formation of Vascular Structures in MSC-OEC} Co-Culture Models

To analyze the effect of fucoidan treatment on the formation of vascular structures on the functional level, we performed co-culture experiments that allow a direct interaction of endothelial cells and bone forming cells, resulting in the formation of microvessel-like structures. For this, OEC were co-cultivated with MSC as well as with the osteosarcoma cell line MG63 to model vascularization processes in both bone formation and bone tumors.

Co-cultures were treated with selected Fucus extracts Fs1 and Fs2. In addition, Fvc was used as reference as it displayed antiangiogenic properties in our previous study [4]. Fs1 and Fs2 were selected due to a high tolerability for both cell types (Figures 1 and 5), combined with a low inflammatory potential in endothelial cells but a high effectivity to modulate angiogenic molecules in OEC and MSC (Figures 4 and 8). Both concentrations (10 and $100 \mu \mathrm{g} / \mathrm{mL}$ ) of Fs1 and Fs2 lowered the number of vascular structures in both types of co-cultures, but results are depicted only for the lower concentration (Figure 9). These findings indicate an antiangiogenic effect of the extracts in accordance with their effects on the growth factors VEGF, ANG-1 and ANG-2, guiding the formation of vascular structures. 
a)

\section{MSC VEGF}

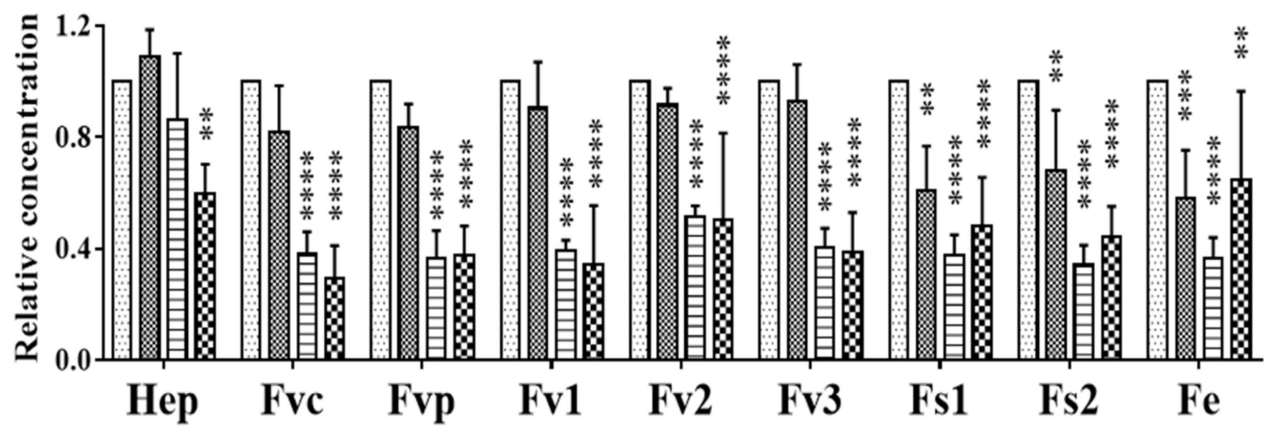

b)

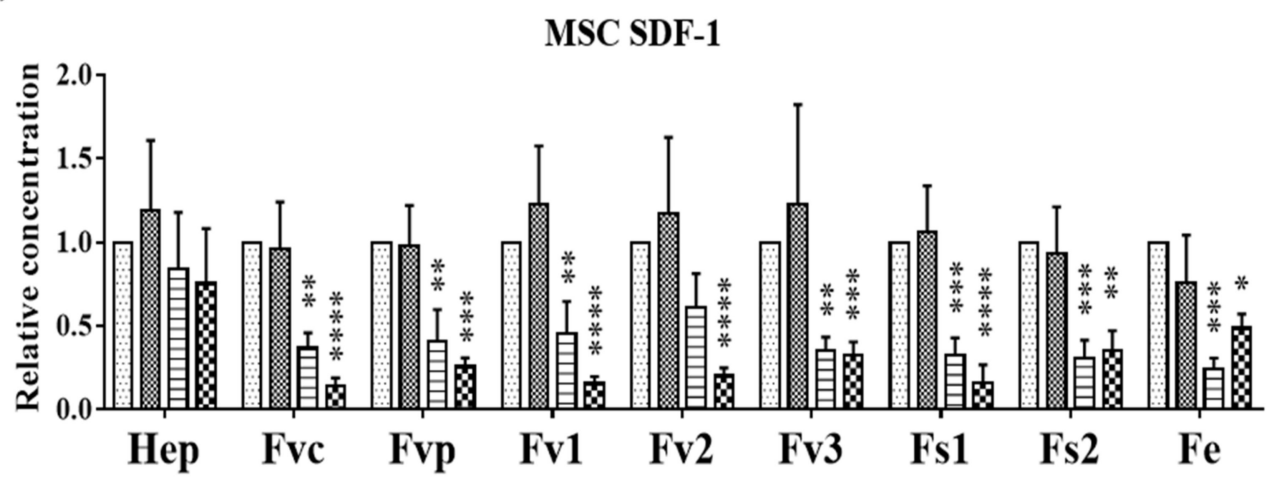

c)

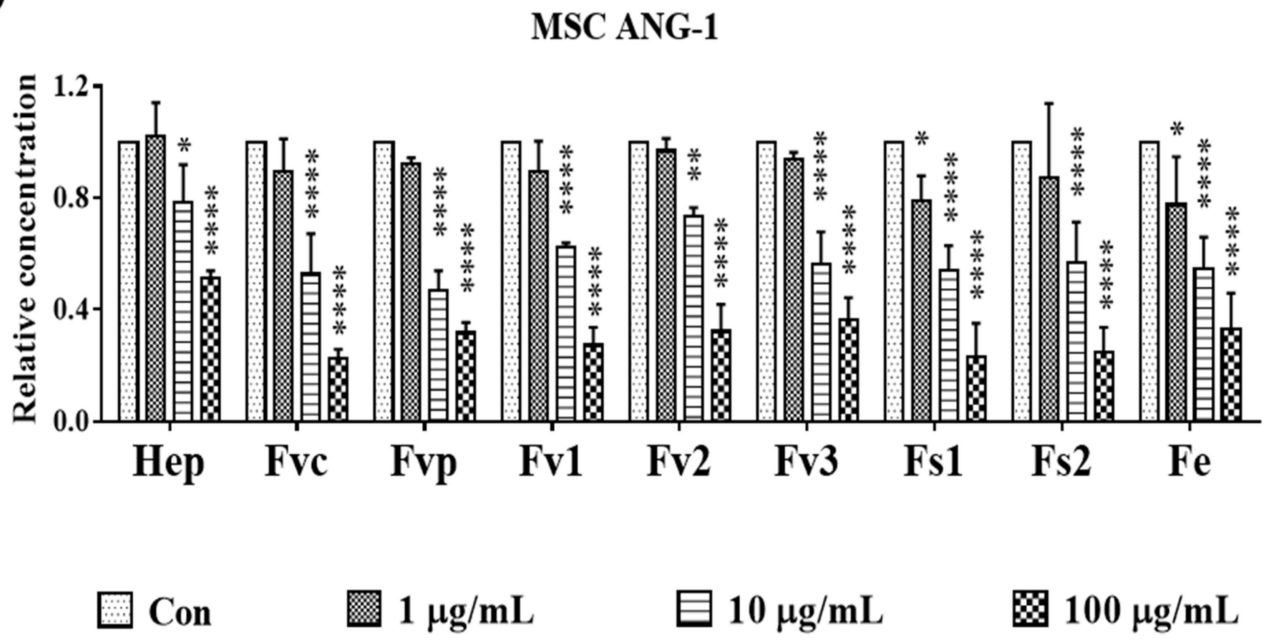

Figure 8. The relative amount of angiogenic growth factors: (a) vascular endothelial growth factor (VEGF), (b) stromal derived factor-1 (SDF-1), and (c) angiopoietin 1 (ANG-1) in supernatant of MSC mono-cultures treated with $100 \mu \mathrm{g} / \mathrm{mL}$ fucoidan/heparin on day 7, measured with enzyme-linked immunosorbent assay. One-way ANOVA, ${ }^{*} p<0.05,{ }^{* *} p<0.01$, ${ }^{* * *} p<0.001,{ }^{* * * *} p<0.0001, n=3$. 
MSC/OEC
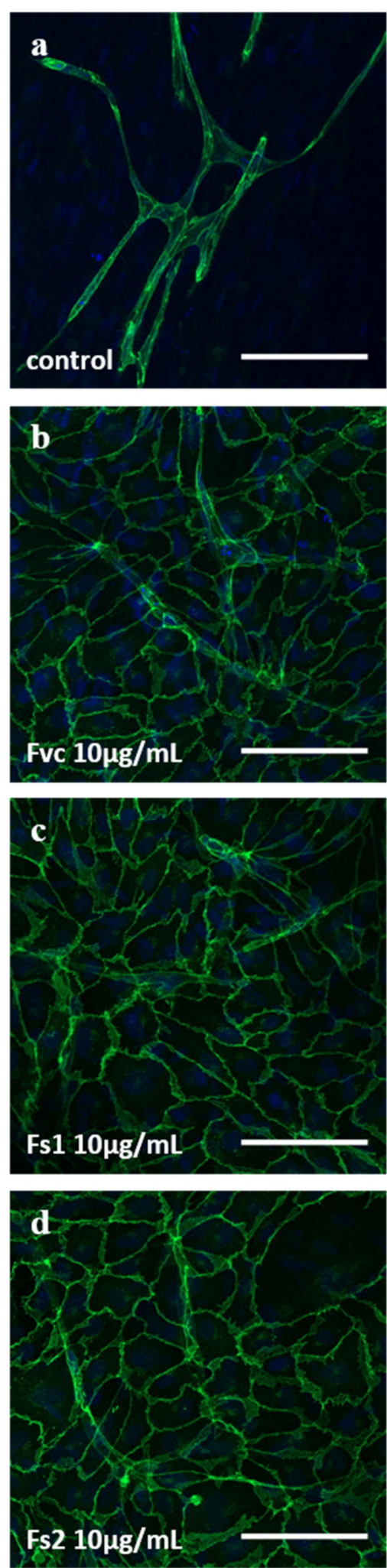

\section{MG63/OEC}
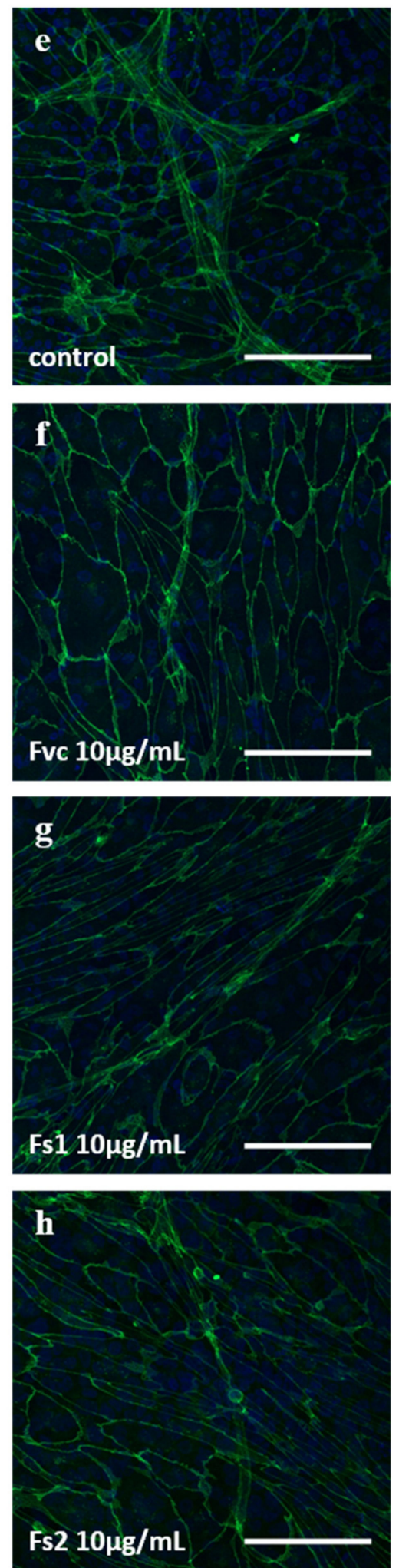

Figure 9. Confocal laser scanning microscopy for: MSC/OEC co-cultures on day 7 for control (a) and $10 \mu \mathrm{g} / \mathrm{mL}$ treatment of Fvc (b), Fs1 (c), and Fs2 (d); MG63/OEC co-cultures on day 7 for control (e) and $10 \mu \mathrm{g} / \mathrm{mL}$ treatment of Fvc (f), Fs1 (g), and Fs2 (h). Endothelial marker VE-cadherin is depicted in green, and nuclei are depicted in blue. The scale bar represents $100 \mu \mathrm{m}$. 


\section{Discussion}

Biomedical applications of compounds require solid data on biological activity and safety, including clear structure-function relationships. Crude fucoidan extracts are multicomponent products and their complex composition impede the structure-function correlations. As numerous studies have shown, the biological properties of fucoidans are highly dependent on their chemical properties, which in turn are tightly related to the species as well as the way they are harvested and extracted [11,26-28]. In this study, we evaluated six crude fucoidan extracts from three Fucus species obtained by different extraction methods. We compared them in terms of several aspects, starting with their chemical properties depending on the extraction procedure and species but mainly focusing on their impact on different cell types involved in bone formation and vascularization or the associated mediator molecules. The study provides a comprehensive data set by combining chemical characterization and biological assessment down to the cellular and molecular level using primary human cells.

Although this study does not specifically focus on a comparison of extraction methods, we noticed that extraction with $100 \mathrm{mM}$ hydrochloric acid $(\mathrm{HCl})$ led to pronounced loss of fucose and sulfate groups (Table 1). These data are in accordance with the literature, indicating that HCL-based extraction and higher acid concentrations interfere with the fucose or sulfate content or provoke degradation of polysaccharides in the extracts $[29,30]$.

In contrast, the three extracts obtained by short-term heating with demineralized water and diluted $(10 \mathrm{mM})$ sulfuric acid had higher fucose contents and DS values. The association between fucose content and DS was shown to be due primarily to the fact that the fucose units in fucoidans are sulfated [31]. In line with previous results $[27,28]$, the treatment at 120 and $100{ }^{\circ} \mathrm{C}$, respectively, was associated with degradation of the fucoidans, but not desulfation.

The tested fucoidan extracts largely varied in their mean MW as well as MW distributions (Table 1 andTable S1). With mean MW ranging between $84 \mathrm{kDa}$ and $730 \mathrm{kDa}$ and their wide MW ranges, they represent high molecular weight fucoidans in accordance with the common consent from literature. Although MW represents an important parameter for the biological activities of fucoidans $[27,28]$, any conclusions regarding the impact of MW are limited by the very high polydisperity of the tested fucoidan extracts, which was even higher when $\mathrm{HCl}$ and sulfuric acid were used for extraction.

Products of natural origin may be contaminated with endotoxins. Therefore, we further analyzed the endotoxin content of the tested fucoidan extracts. Since endotoxins may cause inflammatory and immunological reactions [32,33], parentally applied medical products or materials getting in contact with blood must be endotoxin-free. Especially endothelial cells react highly sensitively toward endotoxins, with release of inflammatory molecules, changes in barrier, and increased angiogenic activity [34,35]. Thus, the evaluation of endotoxins was essential to avoid any artificial results and to exclude potential influences by endotoxins on the investigated parameters described in the following sections.

Fucoidan extracts have differential effects on individual cell types, and their influences further vary in tumor-derived cell lines compared with primary cells [4]. In agreement with previous data from our group [4], endothelial cells compared with MSC tolerated higher doses of the tested fucoidans up to $200 \mu \mathrm{g} / \mathrm{mL}$. Nevertheless, some of the tested extracts influenced the barrier and caused an increased secretion of IL-6, one of the main mediator molecules in inflammatory processes in endothelial cells [20]. If these observations correlate with the fucus species, the individual composition of the extracts or their extraction method cannot be finally clarified in this study. Nevertheless, such influences might correlate with the higher molecular weight, as indicated by the data for Fv1 and Fv2 in this study.

Further, inflammation and changes in the barrier may also influence the formation of vascular structures [36]. Thus, these extracts were excluded in the functional assessment of angiogenesis in the co-cultures. 
In comparison with endothelial cells, MSC were more sensitive in response to fucoidan treatment. MTS values as indicators of metabolic activity were reduced at concentrations of $10 \mu \mathrm{g} / \mathrm{mL}$ or higher for the Fucus vesiculosus extracts. Similar results were reported before by our group for commercially available crude Fucus vesciculosus extracts. Although the extracts Fs1, Fs2, and Fe did not reduce the metabolic activity in MSC, all tested extracts impaired the proliferation of MSC at $100 \mu \mathrm{g} / \mathrm{mL}$, indicated by ECIS measurement. We presently speculate that the reduced proliferation observed at higher doses might be associated with the auto-regulatory function of the growth factor VEGF. Previous publications have demonstrated an autocrine influence of VEGF on MSC proliferation and differentiation [37-39]. Thus, reduced VEGF levels, discussed in more detail in the next sections, may be responsible for impaired proliferation and metabolic activity of MSC.

Fucoidans have been reported to influence vascularization processes [40], although the detailed mechanisms are still not elucidated in detail [41] and even contradictory effects were described in the literature [42]. In our study, the influence of fucoidans on growth factors in the cell culture supernatants was determined using ELISA. All fucoidan extracts significantly lowered the concentrations of VEGF in the supernatants of MSC monocultures in a dose-dependent manner. These data indicate a reliable biological effect even in the context of a primary cell system for the bone, including donor-related variations in growth factor expression or non-homogeneous cell populations in MSC. For the extracts Fs1, Fs2, and $\mathrm{Fe}$, a significant impact was already observed at $1 \mu \mathrm{g} / \mathrm{mL}$, whereas for other extracts concentrations of $10 \mu \mathrm{g} / \mathrm{mL}$ were needed to achieve a significant reduction. For ANG-1, comparable significant effects were observed at the lowest tested dose, confirming the higher effectivity of Fs1 and Fe.

Interestingly, Fs1 and Fe were the extracts with the highest DS, followed by Fv3 and Fs2, potentially responsible for the impact on the VEGF observed at the lowest tested dose. The DS was shown to be an important factor for the pharmacological activities of fucoidans. In our previous study fucose and DS enriched fractions gained from Fucus distichus subsp. evanescence resulted in lower VEGF levels and increased the antiangiogenic properties of these fractions in comparison with their crude counterparts[15]. Thus, high fucose and DS seem to be key features for lowering VEGF levels, resulting in antiangiogenic effects.

Beyond VEGF, which is mainly produced by MSC, ANG-2 produced by endothelial cells [24] is a critical co-factor guiding angiogenesis. The combination of VEGF and ANG-2 is needed to induce new vessel formation and angiogenic activation of endothelial cells [43]. In this study, all tested fucoidans besides Fe reduced ANG-2 produced by endothelial cells. Furthermore, ANG-2 is a factor in inflammation and tumor metastasis [44]. In addition, the chemokine SDF-1, involved in stem- and inflammatory cell recruitment [45], vascularization [46], and osteosarcoma metastasis [47,48], was consistently reduced by all tested extracts.

Although effects on the angiogenic mediator are important parameters to indicate a therapeutical potential of fucoidans to control angiogenesis, vascularization processes are highly complex and dynamic and underlie a spatial and temporal control of multiple factors. Accordingly, evaluation of pro- or antiangiogenic properties of fucoidans should be supported by functional evaluation in a defined physiological context. For functional evaluation, we have chosen two co-culture models, allowing direct interactions between endothelial cells and bone cells [24,49]. In one, we used MSC to model bone formation; in the other one, we used the tumor cell line MG63 to model osteosarcoma. The selected extracts for these experiments, Fs1 and Fs2, showed antiangiogenic properties in both coculture systems. The results were similar to previous reports using commercially available high molecular weight fucoidan [4]. The antiangiogenic effect in this present and in our previous study correlated with reduced concentrations of the growth factors VEGF, ANG-2, and ANG-1 in a very consistent and dose-dependent manner. All tested extracts resembled mainly HMW fucoidan but with variations in the molecular weight. A recent study by Gupta et al. showed antiproliferative effects of fucoidans on the osteosarcoma cell line MG63 depending on the species and molecular weight, resulting in the G1 arrest 
for high and medium molecular weight fucoidan treated cells [50]. Although MSC used in this present study proliferate more slowly compared to MG63, we observed to some extent similar effects for MSC, indicating that high molecular weight fucoidan may impair osteogenic cells' metabolic activity and proliferation.

\section{Materials and Methods}

\subsection{Fucoidan Extraction}

Fucus vesiculosus (Fv), Fucus serratus (Fs), and Fucus subs. evanescens (Fe) were harvested in Kiel, Germany, and used for the extraction of crude fucoidan as described in detail by Ptak et al. [51]. All seaweeds were initially soaked in $85 \%$ ethanol solution overnight, followed by a wash with acetone. After drying, the fucoidans were extracted. The extracts Fs1 and Fs2 were extracted from Fucus serratus (harvested in October) with $10 \mathrm{mM}$ sulfuric acid at $100{ }^{\circ} \mathrm{C}$ for $30 \mathrm{~min}$ (Fs1) and $100 \mathrm{mM}$ hydrochloric acid at $80{ }^{\circ} \mathrm{C}$ (Fs2) for $30 \mathrm{~min}$, respectively, using microwave-assisted extraction. The extracts were subsequently neutralized with $1 \mathrm{M}$ sodium hydroxide and transferred to a conical tube. A strong solution (35\%) of calcium chloride was added to the extracts to reach a final concentration of $1 \%$ in each tube. The extracts were then centrifuged $\left(30 \mathrm{~min}\right.$ at $\left.4{ }^{\circ} \mathrm{C}\right)$, and the supernatant was transferred to a new conical tube. Ethanol (96\%) was added to each tube for a final concentration of $40 \%$. After the addition of ethanol, the extracts were centrifuged, and the supernatant was recovered. A final addition of ethanol was applied for a concentration of $70 \%$, and the extracts were centrifuged a final time. The pellet was recovered and washed with ethanol and acetone and left to dry. After drying, the pellet was solubilized in demineralized water and dialyzed (MWCO $=12-14 \mathrm{kDa}$ ) until the conductivity of the surrounding water no longer increased. After dialysis, the extracts were freeze-dried and analyzed for chemical characterizations. For the following extracts, purification was performed as previously described unless stated otherwise. The crude fucoidan extract Fv1 was prepared by soaking F. vesiculosus (harvested in July) in $100 \mathrm{mM}$ hydrochloric acid for $24 \mathrm{~h}$, followed by neutralization with $1 \mathrm{M}$ sodium hydroxide. Fv2 was similarly prepared as Fv1 from Fucus vesiculosus (harvested in October); however, the soaking and decanting step was repeated twice for three soaking steps in total. Fv3 was extracted from Fucus vesiculosus (harvested in October) with demineralized water at $120{ }^{\circ} \mathrm{C}$ for 30 min using microwave-assisted extraction. Fe was prepared from Fucus distichus subsp. evanescens (in July) and extracted similarly to Fv3. Specification of extracts and isolation are summarized in Table 3.

Table 3. Comparison in fucoidan extraction for the 6 samples.

\begin{tabular}{|c|c|c|c|c|c|}
\hline \multirow{2}{*}{ Ex. } & \multirow{2}{*}{ Species } & \multirow{2}{*}{ Harvest } & \multicolumn{3}{|l|}{ Extracted } \\
\hline & & & in & at & for \\
\hline Fv1 & F. vesiculosus & July & $100 \mathrm{mM}$ hydrochloric acid & RT & $24 \mathrm{~h}$ \\
\hline Fv2 & F. vesiculosus & October & $100 \mathrm{mM}$ hydrochloric acid $\times 3$ & RT & $24 \mathrm{~h}$ \\
\hline Fv3 & F. vesiculosus & October & demineralized water * & $120^{\circ} \mathrm{C}$ & $30 \mathrm{~min}$ \\
\hline $\mathrm{Fe}$ & F. evanescens & July & demineralized water ${ }^{*}$ & $120^{\circ} \mathrm{C}$ & $30 \mathrm{~min}$ \\
\hline Fs1 & F. serratus & October & 10 mM sulfuric acid * & $100^{\circ} \mathrm{C}$ & $30 \mathrm{~min}$ \\
\hline Fs2 & F. serratus & October & $100 \mathrm{mM}$ hydrochloric acid * & $80^{\circ} \mathrm{C}$ & $30 \mathrm{~min}$ \\
\hline
\end{tabular}

Ex.: extracts; * microwave assisted; RT: room temperature.

\subsection{Chemical Characterization}

\subsubsection{Elemental Analysis}

The content of hydrogen, carbon, nitrogen, and sulfur was determined by elemental analysis as described previously [16]. The degree of sulfation (DS, number of sulfate group per monosaccharide) was calculated using the determined sulfur content (\%) [16]. The total protein content was estimated by multiplying the nitrogen content (\%) by 6.25 . 


\subsubsection{Monosaccharide Composition by GLC}

To determine the neutral monosaccharide composition, acetylation analysis of the fucoidans was performed as previously reported [16]. Briefly, the fucoidans were hydrolyzed using 2M TFA [52], converted into alditol acetate derivatives (AA) by reduction and acetylation [18]. The AA derivatives were separated by gas-liquid chromatography (GLC), and the percentage of the respective AA was calculated.

\subsubsection{SEC-MALS-VIS Analysis}

The molecular mass of the fucoidans was measured by size-exclusion chromatography (SEC) using an HPLC system equipped with multi-angle light scattering (MALS), viscometry (VIS) and refractive index (RI) detectors. The separation of the samples was achieved using an Agilent 1260 series quaternary pump with an OHPak LB-806M (8.0 mmID X 300 mmL; ShodexTM, Agilent, Waldbronn, Germany). The column outlet was connected to HELEOS-II MALS photometer (Wyatt Technology, Dernbach, Germany), followed by a ViscoStar III differential viscometer and an Optilab T-rEX differential refractometer (Wyatt Technology, Dernbach, Germany). The eluent was PBS buffer solution (50 $\mathrm{mM} \mathrm{Na} 2 \mathrm{HPO}_{4}-\mathrm{NaH}_{2} \mathrm{PO}_{4}$ and $150 \mathrm{mM} \mathrm{NaCl}, \mathrm{pH} 7.0$ ), and the flow rate was $0.7 \mathrm{~mL} / \mathrm{min}$. The fucoidan samples $(2 \mathrm{mg} / \mathrm{mL})$ were filtered $(0.45 \mu \mathrm{m})$ before injection. The injection volume was $100 \mu \mathrm{L}$. The used $\mathrm{dn} / \mathrm{dc}$ was 0.150 as previously described for fucoidans [17]. The data were collected and processed using the Astra (v.7.3.2) software (Wyatt Technology, Dernbach, Germany).

\subsection{EndoLISA ${ }^{\circledR}$ Endotoxicity Assay}

Freeze-dried fucoidan extracts were solubilized at a concentration of $5 \mathrm{mg} / \mathrm{mL}$ in water and sterilized by sterile filtration through $0.2 \mu \mathrm{m}$ filter. Only fully soluble extracts were used for the biological assessment.

EndoLISA ${ }^{\circledR}$ kit (Hyglos, Germany) was used to determine the endotoxin content of the fucoidan samples according to the manufacturer's instruction. The fucoidan samples were diluted to $100 \mu \mathrm{g} / \mathrm{mL}$. Both samples and standards were prepared in duplicates and applied to the pre-treated lipopolysaccharide (LPS)-specific phage-binding plate, followed by adding the binding buffer and incubation overnight ( $18 \mathrm{~h} \mathrm{mixing} \mathrm{at} 450 \mathrm{rpm}$ and $37^{\circ} \mathrm{C}$ ). After 3 washing steps to remove the matrix substances, assay reagent was applied. The fluorescence after $90 \mathrm{~min}$ was read at 380/445 $\mathrm{nm}$ of excitation/emission wavelength, and the relative fluorescence unit was calculated. The endotoxin content of fucoidan samples was calculated from a standard curve.

\subsection{Ethical Approval for the Use of Human Cells}

The MSC and OEC were isolated from human tissues. The use of human tissue and cells was approved by the local ethical advisory boards, including the consent from the individual donors.

\subsection{Isolation and Culture of Human Mesenchymal Stem Cells (MSCs)}

Human mesenchymal stem cells (MSCs) were isolated from bone tissue fragments from femoral head as described by our group before [24,25]. In brief, bone marrow cells from cancellous bone structures were collected by washing bone fragments in tissue buffer (Medium 199), GlutaMaxTM (Gibco, Darmstadt, Germany), 20\% fetal bovine serum (FBS) (Sigma, Taufkirchen, Germany), 1\% penicillin/streptomycin (Pen/Strep) (Biochrom, Berlin, Germany), 1\% fungizone (Biozol, Eching, Germany), and 1\% ciprobay (FRESENIUS KABI, Bad Homburg, Germany). After centrifugation, cells were plated at a density of $2 \times 10^{6}$ cells $/ \mathrm{cm}^{2}$ to collagen type I (Corning, Bedford, MA, USA) coated flasks in Dulbecco's Medium Essential Medium (DMEM)/Ham F-12 (Biochrom, Berlin, Germany) supplemented with $20 \%$ FBS and $1 \%$ Pen/Strep. Cells from passage 2 on cells were cultivated in osteogenic differentiation medium (ODM). ODM consisted of DMEM/Ham F-12, $0.1 \mu \mathrm{M}$ dexamethasone (Sigma-Aldrich, St. Louis, MO, USA), $10 \mathrm{mM} \beta$-glycerol 
phosphate (Sigma-Aldrich, St. Louis, MO, USA), $50 \mu \mathrm{M}$ ascorbic acid-2-phosphate (SigmaAldrich, St. Louis, MO, USA), 10\% FBS, and 1\% Pen/Strep. Cells were maintained for at least 2 weeks in ODM to obtain MSC with an osteogenic phenotype. Cells used in the presented study were in passage from 2 to 4 and were gained from MSC donors at the age of $78(\mathrm{~m}), 69(\mathrm{f})$, and $48(\mathrm{~m})$.

\subsection{Isolation and Culture of Human Outgrowth Endothelial Cells (OECs)}

Human outgrowth endothelial cells (OECs) from peripheral blood were isolated and cultured by the methods described previously [53,54]. Briefly, human mononuclear cells were isolated from buffy coat by gradient centrifugation using Biocoll (Biochrom, Berlin, Germany). After being resuspended in Endothelial Cell Growth Medium 2 (ECGM2) (PromoCell, Heidelberg, Germany) with supplements from the kit, 5\% FBS, and 1\% Pen/Strep, cells were seeded in collagen type I coated 24-well plates at a density of $2.6 \times$ $10^{6}$ cells $/ \mathrm{cm}^{2}$ and further sub-cultured to new collagen type I coated 24-well plates after 7 days. Within 2-3 weeks, cobblestone-like OECs appeared, and cells were expanded for the experiments. Cells (passage 6-7) in the presented study were from buffy coat donors at the age of 59 (f), 25 (f), 20 (f), and 66 (m).

\subsection{Cell Seeding and Fucoidan Treatment of Individual Cell Types}

MSC or OEC were seeded at a density of 40.000 cells $/ \mathrm{cm}^{2}$ to multi-well plates coated with fibronectin for OEC monocultures and with collagen I (Corning, Badford, MA, USA) for MSC mono-cultures (Millipore, Temecula, CA, USA).

MSCs were cultured in ODM; OECs were maintained in ECGM-2. One day after seeding, the cells were treated with the fucoidan extracts described in Table 1 and commercial fucoidan extracts (Sigma, F5631-1G and F8190, Sigma, Taufkirchen, Germany) as well as heparin (physico-chemical analysis, Y0001282) at different concentrations in cell medium. The treatment was exchanged every 3 days along with medium exchange.

\subsection{MTS Cell Metabolic Activity Assay}

The metabolic activity of cells was determined with CellTiter $96^{\circledR}$ AQueous One Solution Cell Proliferation Assay (Promega, Madison, WI, USA). MSC or OECs were seeded on 96-well plates at a density of 40.000 cells $/ \mathrm{cm}^{2}$. Cells were treated with concentrations of $1,10,50,100$, and $200 \mu \mathrm{g} / \mathrm{mL}$ fucoidan extracts and heparin. To characterize cell metabolic activity, the cells were incubated with MTS solution (1:6 diluted in medium) at $37^{\circ} \mathrm{C}$ for $2 \mathrm{~h}$. The absorbance at $490 \mathrm{~nm}$ was measured using a microplate reader. The cellular metabolic activity was calculated relative to the control group (100\%) after subtracting the background absorbance.

\subsection{LDH Cytotoxicity Assay}

To determine the cytotoxicity of fucoidan extracts and heparin in MSC or OEC at different concentrations, we performed LDH (lactate dehydrogenase) assay (Thermo Scientific, Rockford, IL, USA) at 24, 72, and $168 \mathrm{~h}$ after treatment using the cell culture supernatants as described in the previous section and the protocol according to manufacturer. First, the maximum LDH control was prepared by adding lysis buffer to cells in technical triplicates. After 45 min incubation at $37^{\circ} \mathrm{C}$, the supernatants were transferred to a 96 -well plate and reaction mixture was added. After $30 \mathrm{~min}$ incubation at room temperature, the stop solution was applied, and the OD was measured at 490 and $680 \mathrm{~nm}$ on a plate reader. The absorbance at $680 \mathrm{~nm}$ was subtracted from the absorbance at $490 \mathrm{~nm}$, and the cytotoxicity was calculated as a percentage relative to the maximum LDH activity control.

\subsection{Immunofluorescence Staining and Visualization of OECs}

OECs were seeded on fibronectin coated Thermanox coverslips (Thermo scientific, Rochester, NY, USA) in 24-well plates at a density of 40.000 cells $/ \mathrm{cm}^{2}$. OECs were treated with fucoidan extracts for 7 days and fixed with $4 \%$ paraformaldehyde in phosphate 
buffered saline (PBS) (Affymetrix, Cleveland, OH, USA), followed by 3 times of a 5 min wash with PBS and 10 min permeabilization with $0.5 \%$ Triton ${ }^{\circledR}$ X-100. Cells were incubated with VE-cadherin (R\&D, Minneapolis, MN, USA) antibody (1:50 diluted in PBS with 1\% bovine serum albumin (BSA)) for $1.5 \mathrm{~h}$ and with the secondary antibody (1\% BSA in PBS) for $30 \mathrm{~min}$ after being washed with PBS 3 times for $5 \mathrm{~min}$. Cells were incubated for 10 min with Hoechst $(2 \mu \mathrm{g} / \mathrm{mL}$ in PBS). The cells on Thermanox coverslips were mounted with Fluoromount Aqueous Mounting Medium (Sigma-Aldrich, St. Louis, MO, USA) for subsequent visualization with confocal laser scanning microscopy (CLSM, LSM 510 Meta, Zeiss, Oberkochen, Germany).

\subsection{Electrical Cell-Substrate Impedance Sensing (ECIS) for MSC and OEC}

OECs were seeded to $8 \mathrm{~W} 10 \mathrm{E}$ slides coated with fibronectin (Applied BioPhysics, Troy, NY, USA) at a density of 40.000 cells $/ \mathrm{cm}^{2}$ in ECGM-2 medium. Then, cells were cultured for 3 days in ECGM-2 to reach 100\% confluence and to establish a tight cell barrier before the cells were treated for 7 days with fucoidan and heparin while monitoring the impedance. The impedance as a percentage in relation to the control was analyzed.

For MSC, cells were seeded at a lower density of $5000 \mathrm{cells} / \mathrm{cm}^{2}$ on the collagen I coated 8W10E slides in order to monitor the impedance as an indicator of MSC proliferation. The cells were treated the second day after seeding. The impedance values were recorded for 7 days with ECIS (applied biophysics, Troy, NY, USA). The mean values were calculated after subtracting blank values for each condition.

\subsection{Quantification of DNA Content}

The double-stranded DNA content of MSC mono-cultures in 24-well plates was determined to analyze the impact of fucoidans on the cellular proliferation. DNA content was determined with Quant-iT PicoGreen dsDNA assay kit (Molecular probes, Eugene, OR, USA). To prepare the DNA aqueous solution, cells were trypsinized in 24-well plates. After centrifuging the cell suspension for $5 \mathrm{~min}$ at $2000 \mathrm{~g}$, cell pellets were collected and resuspended in $1 \mathrm{~mL}$ deionized water. Cell membranes were ruptured to release DNA by three freeze-thaw cycles and two $15 \mathrm{~s}$ sonications. Samples and standards were prepared in triplicates. DNA amount was determined by measuring the fluorescence using a microplate reader (TECAN, Maennedorf, Switzerland) at 485/535 nm of excitation/emission wavelength.

\subsection{Gene Expression Analysis}

Total RNA isolation from MSCs and OECs was performed according to the manufacturer's protocol using Total RNA Kit (VWR peqlab, Erlangen, Germany). The RNA concentration was determined with a NanoDrop (Thermo Fisher, Erlangen, Germany). Then, $1 \mu \mathrm{g}$ of total RNA per sample was transcribed to cDNA with high capacity RNA-tocDNA Kit (Applied Biosystems, Carlsbad, CA, USA). PCR was performed using primers as indicated in Table 4 using RPL13a as an internal control gene. Quantitative real-time PCR was carried out using a total volume of $20 \mu \mathrm{L}$ for each reaction. The mastermix contained SYBR $^{\circledR}$ Select Master Mix (Applied Biosystems, Austin, TX, USA), cDNA QuantiTect ${ }^{\circledR}$ Primer Assay (Qiagen, Hilden, Germany), RNase free water (Qiagen), and 3.2 $\mu \mathrm{L}$ cDNA. The mixtures were preheated to $50^{\circ} \mathrm{C}$ for $20 \mathrm{~min}$ and $95^{\circ} \mathrm{C}$ for $20 \mathrm{~min}$, followed by 40 cycles of $95^{\circ} \mathrm{C}$ for $15 \mathrm{~s} \mathrm{(step} \mathrm{1)} \mathrm{and} 60^{\circ} \mathrm{C}$ for $60 \mathrm{~s}$ (step 2). The relative gene expression was calculated with the $\Delta \Delta \mathrm{cT}$ method. Fucoidan or heparin treated groups were normalized to untreated controls. 
Table 4. Primer List for individual molecules and internal housekeeping gene (RPL13A).

\begin{tabular}{ccc}
\hline Gene Name & \multicolumn{1}{c}{ Primer Assay } & Catalogue No. \\
\hline ALP & Hs_ALPL_1_SG QuantiTect Primer Assay & QT00012957 \\
Angiopoietin 1 & Hs_ANGPT1_1_SG QuantiTect Primer Assay & QT00046865 \\
Angiopoietin 2 & Hs_ANGPT2_1_SG QuantiTect Primer Assay & QT00100947 \\
Osteocalcin & Hs_BGLAP_1_SG QuantiTect Primer Assay & QT00232771 \\
ICAM & Hs_ICAM1_1_SG QuantiTect Primer Assay & QT00074900 \\
IL-6 & Hs_IL6_1_SG QuantiTect Primer Assay & QT00083720 \\
SDF-1 & Hs_CXCL12_1_SG QuantiTect Primer Assay & QT00087591 \\
VCAM-1 & Hs_VCAM1_1_SG QuantiTect Primer Assay & QT00018347 \\
VEGF & Hs_VEGFA_2_SG QuantiTech Primer Assay & QT01036861 \\
RPL13A & Hs_RPL13A_1_SG QuantiTect Primer Assay & QT00089915 \\
\hline
\end{tabular}

\subsection{Enzyme Linked Immunosorbent Assay (ELISA)}

To examine the protein levels in supernatant, the sample supernatants were collected to perform IL-6, ICAM-1, and angiopoietin 2 ELISA for OEC mono-cultures and, respectively, VEGF, SDF-1, and angiopoietin 1 ELISA for MSC mono-cultures using the Duo-Set ELISA Development kits (R\&D, Minneapolis, MN, USA) according to the manufacturer's protocols. The optical absorbance was detected by a microplate reader at $450 \mathrm{~nm}$ with a reference wavelength of $560 \mathrm{~nm}$. The protein levels were presented relative to the controls.

\subsection{Quantitative Analysis of Osteogenesis}

To quantitatively determine the influence of $100 \mu \mathrm{g} / \mathrm{mL}$ fucoidan on the calcification level in MSC mono-cultures at day 14, $1 \mathrm{~mL}$ of $40 \mathrm{mM}$ Alizarin Red S Stain Solution (Millipore, Billerica, MA, USA) was applied to $4 \%$ PFA (paraformaldehyde) fixed cell monolayers in 24-well plates and incubated for $30 \mathrm{~min}$. Cells were washed with distilled water until the wash solution became colorless and were incubated with $10 \%(w / v)$ cetylpyridinium chloride (CPC) (Roth, Karlsruhe, Germany) overnight to extract the Alizarin Red. Extracts were added to a 96-well plate containing standards prepared as well in 10\% CPC. Absorbance of the samples was measured at a wavelength of $560 \mathrm{~nm}$ in a microplate reader.

\subsection{Alkaline Phosphatase (ALP) Activity Assay}

To measure the impact of fucoidan in MSC mono-cultures on ALP activity, the supernatant was collected 7 days after treating with 1,10 , and $100 \mu \mathrm{g} / \mathrm{mL}$ fucoidan, and an alkaline phosphatase assessment was performed according to the manufacturer's protocol from the kit (Abcam, Germany). In brief, samples and standards were prepared in triplicates in 96-well plates for ALP reaction with pNPP Solution. Stop solution was added to the control wells before starting the ALP reaction to determine the background values. After $60 \mathrm{~min}$ incubation, the reaction in samples was stopped by stop solution, and the OD value was measured at $405 \mathrm{~nm}$ with a microplate reader. The values were calculated after background subtraction and are presented relative to the control.

\subsection{Co-Cultures}

MSC or the osteosarcoma cell line MG63 (ATCC, Wesel, Germany) were seeded at a density of 40.000 cells $/ \mathrm{cm}^{2}$ on collagen I (Corning, Badford, MA, USA) coated Thermanox coverslips in 24-well plates. Then, OECs were added to MSC or MG63 cultures the second day in the same seeding density. The co-cultures were maintained in ECGM-2 and treated with 10 or $100 \mu \mathrm{g} / \mathrm{mL}$ fucoidan extracts (Fvc, Fs1, and Fs2) one day after seeding OECs. Cells were fixed with $4 \%$ PFA and stained on day 7 as described in 2.10.

\subsection{Statistical Analysis}

All experiments mentioned above were carried out with cells from at least 3 different donors. The statistical significance of the results was assessed with unpaired one-way ANOVA or two-way ANOVA using Graphpad Prism 7. As indicated in the corresponding 
result sections, $p<0.05\left({ }^{*} p<0.05,{ }^{* *} p<0.01,{ }^{* * *} p<0.001{ }^{* * * *} p<0.0001\right)$ was considered as statistically significant.

\section{Conclusions}

In conclusion, crude fucoidan extracts isolated from different fucus species represented mixtures of HMW fucoidans. Tested extracts consistently lowered important molecular mediators involved in angiogenesis in endothelial cells and MSC in vitro, but the doses needed to achieve a significant reduction differed amongst the extracts. In this context, the degree of sulfation seems to be a critical factor. The antiangiogenic effect was confirmed at the functional level in in vitro models mimicking vascularization in bone repair or bone tumors. Thus, HMW might be more useful in osteosarcoma treatment and less suitable for bone regeneration-something to be tested in in vivo models in the future.

Supplementary Materials: The following are available online at https:/ / www.mdpi.com/article/10 $.3390 /$ md19040194/s1. Figure S1: Molecular mass-versus-elution time plots for (A) three fucoidans from F. vesiculosus (Fv1, Fv2 and Fv3) and (B) two fucoidans from F. serratus (Fs1 and Fs2) as well as one from F. distichus subsp. evanescens (Fe). RI chromatogram is overlayed in all plots, Figure S2: (A) Differential molecular mass distribution and (B) cumulative molecularar mass distribution analyses of three fucoidans from F. vesiculosus (Fv1, Fv2 and Fv3), two fucoidans from F. serratus (Fs1 and Fs2), and one from F. distichus subsp. evanescens (Fe). Differential distribution plot is the visual representatio of multimodal (more than one peak) or monomodal composition of the sample, while the cumulative distribution plot shows the weight fraction of certain molecular mass range, Figure S3. Relative gene expression for the inflammatory response relevant molecules a) IL-6, b) ICAM-1 and c) VCAM evaluated by semi-quantitative RT-PCR for mono-cultures of OEC treated with $100 \mu \mathrm{g} / \mathrm{mL}$ fucoidan on day 7. 1-way ANOVA. ${ }^{*} p<0.05,{ }^{* *} p<0.01 . \mathrm{n}=3$, Figure S4. Relative gene expression for the angiogenic molecules a) VEGF, b) SDF-1, c) ANGPT-1 for MSCs and d) ANGPT-2 for OECs with $100 \mu \mathrm{g} / \mathrm{mL}$ fucoidan and Heparin treatment evaluated by semi-quantitative RT-PCR on day 7 . 1-way ANOVA. ${ }^{*} p<0.05,{ }^{* *} p<0.01 . \mathrm{n}=3$.

Author Contributions: Conceptualization, S.F., X.F., and S.A.; data acquisition and methodology F.W., Y.X., S.N., S.H.P., R.R., J.O., and J.X.; formal analysis, F.W., Y.X., R.R., S.N., and S.F.; writingoriginal draft preparation, F.W., S.N., S.H.P., and S.F.; writing-review and editing, S.F., S.N., and S.A.; visualization, F.W. and S.N.; supervision, S.F., A.S., X.F., and S.A.; project administration, S.F., X.F., and S.A.; funding acquisition, S.F., X.F., and S.A. All authors have read and agreed to the published version of the manuscript.

Funding: This work was supported by the Interreg Project "FucoSan".

Institutional Review Board Statement: The study was conducted according to the guidelines of the Declaration of Helsinki, and approved by the Institutional Review Board (Medical Faculty, Kiel University, AZ 466/11 (23.11.11), AZ 296/11 (09.11.11), D500/19 (15.07.19)).

Informed Consent Statement: Informed consent was obtained from all subjects involved in the study.

Data Availability Statement: Data is contained within the article or supplementary material.

Acknowledgments: We want to thank Anne-Rose Nissen and Angelika Duttmann for their excellent technical support.

Conflicts of Interest: The authors declare no conflict of interest.

\section{References}

1. Park, J.; Cha, J.D.; Choi, K.M.; Lee, K.Y.; Han, K.M.; Jang, Y.S. Fucoidan inhibits LPS-induced inflammation in vitro and during the acute response in vivo. Int. Immunopharmacol. 2017, 43, 91-98. [CrossRef] [PubMed]

2. Takahashi, H.; Kawaguchi, M.; Kitamura, K.; Narumiya, S.; Kawamura, M.; Tengan, I.; Nishimoto, S.; Hanamure, Y.; Majima, Y.; Tsubura, S.; et al. An Exploratory Study on the Anti-inflammatory Effects of Fucoidan in Relation to Quality of Life in Advanced Cancer Patients. Integr. Cancer Ther. 2018, 17, 282-291. [CrossRef]

3. Ni, L.; Wang, L.; Fu, X.; Duan, D.; Jeon, Y.J.; Xu, J.; Gao, X. In vitro and in vivo anti-inflammatory activities of a fucose-rich fucoidan isolated from Saccharina japonica. Int. J. Biol. Macromol. 2020, 156, 717-729. [CrossRef] 
4. Wang, F.; Schmidt, H.; Pavleska, D.; Wermann, T.; Seekamp, A.; Fuchs, S. Crude Fucoidan Extracts Impair Angiogenesis in Models Relevant for Bone Regeneration and Osteosarcoma via Reduction of VEGF and SDF-1. Mar. Drugs 2017, 15, 186. [CrossRef] [PubMed]

5. Cong, Q.; Chen, H.; Liao, W.; Xiao, F.; Wang, P.; Qin, Y.; Dong, Q.; Ding, K. Structural characterization and effect on anti-angiogenic activity of a fucoidan from Sargassum fusiforme. Carbohydr. Polym. 2016, 136, 899-907. [CrossRef] [PubMed]

6. Cui, C.; Wang, P.; Cui, N.; Song, S.; Liang, H.; Ji, A. Stichopus japonicus Polysaccharide, Fucoidan, or Heparin Enhanced the SDF-1 $\alpha$ /CXCR4 Axis and Promoted NSC Migration via Activation of the PI3K/Akt/FOXO3a Signaling Pathway. Cell Mol. Neurobiol. 2016, 36, 1311-1329. [CrossRef]

7. Brandi, M.L.; Collin-Osdoby, P. Vascular biology and the skeleton. J. Bone Miner. Res. 2006, 21, 183-192. [CrossRef]

8. Schipani, E.; Maes, C.; Carmeliet, G.; Semenza, G.L. Regulation of Osteogenesis-Angiogenesis Coupling by HIFs and VEGF. J. Bone Miner. Res. 2009, 24, 1347-1353. [CrossRef] [PubMed]

9. Sivaraj, K.K.; Adams, R.H. Blood vessel formation and function in bone. Development 2016, 143, 2706-2715. [CrossRef] [PubMed]

10. Zayed, A.; El-Aasr, M.; Ibrahim, A.S.; Ulber, R. Fucoidan Characterization: Determination of Purity and Physicochemical and Chemical Properties. Mar. Drugs 2020, 18, 571. [CrossRef] [PubMed]

11. Ale, M.T.; Mikkelsen, J.D.; Meyer, A.S. Important determinants for fucoidan bioactivity: A critical review of structure-function relations and extraction methods for fucose-containing sulfated polysaccharides from brown seaweeds. Mar. Drugs 2011, 9, 2106-2130. [CrossRef]

12. Zayed, A.; Ulber, R. Fucoidan production: Approval key challenges and opportunities. Carbohydr. Polym. 2019, $211,289-297$. [CrossRef]

13. Alwarsamy, M.; Gooneratne, R.; Ravichandran, R. Effect of fucoidan from Turbinaria conoides on human lung adenocarcinoma epithelial (A549) cells. Carbohydr. Polym. 2016, 152, 207-213. [CrossRef]

14. Zayed, A.; Hahn, T.; Finkelmeier, D.; Burger-Kentischer, A.; Rupp, S.; Krämer, R.; Ulber, R. Phenomenological investigation of the cytotoxic activity of fucoidan isolated from Fucus vesiculosus. Process Biochem. 2019, 81, 182-187. [CrossRef]

15. Ohmes, J.; Xiao, Y.; Wang, F.; Mikkelsen, M.D.; Nguyen, T.T.; Schmidt, H.; Seekamp, A.; Meyer, A.S.; Fuchs, S. Effect of Enzymatically Extracted Fucoidans on Angiogenesis and Osteogenesis in Primary Cell Culture Systems Mimicking Bone Tissue Environment. Mar. Drugs 2020, 18, 481. [CrossRef] [PubMed]

16. Lahrsen, E.; Liewert, I.; Alban, S. Gradual degradation of fucoidan from Fucus vesiculosus and its effect on structure, antioxidant and antiproliferative activities. Carbohydr. Polym. 2018, 192, 208-216. [CrossRef] [PubMed]

17. Neupane, S.; Bittkau, K.S.; Alban, S. Size distribution and chain conformation of six different fucoidans using size-exclusion chromatography with multiple detection. J. Chromatogr. A 2020, 1612, 460658. [CrossRef] [PubMed]

18. Blakeney, A.B.; Harris, P.J.; Henry, R.J.; Stone, B.A. A simple and rapid preparation of alditol acetates for monosaccharide analysis. Carbohydr. Res. 1983, 113, 291-299. [CrossRef]

19. Piconi, L.; Quagliaro, L.; Da Ros, R.; Assaloni, R.; Giugliano, D.; Esposito, K.; Szabo, C.; Ceriello, A. Intermittent high glucose enhances ICAM-1, VCAM-1, E-selectin and interleukin-6 expression in human umbilical endothelial cells in culture: The role of poly(ADP-ribose) polymerase. J. Thromb. Haemost 2004, 2, 1453-1459. [CrossRef] [PubMed]

20. Reinhart, K.; Bayer, O.; Brunkhorst, F.; Meisner, M. Markers of endothelial damage in organ dysfunction and sepsis. Crit. Care Med. 2002, 30 (Suppl. 5), S302-S312. [CrossRef]

21. Mochizuki, Y.; Nakamura, T.; Kanetake, H.; Kanda, S. Angiopoietin 2 stimulates migration and tube-like structure formation of murine brain capillary endothelial cells through c-Fes and c-Fyn. J. Cell Sci. 2002, 115, 175-183. [PubMed]

22. Yamaguchi, J.; Kusano, K.F.; Masuo, O.; Kawamoto, A.; Silver, M.; Murasawa, S.; Bosch-Marce, M.; Masuda, H.; Losordo, D.W.; Isner, J.M.; et al. Stromal cell-derived factor-1 effects on ex vivo expanded endothelial progenitor cell recruitment for ischemic neovascularization. Circulation 2003, 107, 1322-1328. [CrossRef] [PubMed]

23. Liekens, S.; Schols, D.; Hatse, S. CXCL12-CXCR4 Axis in Angiogenesis, Metastasis and Stem Cell Mobilization. Curr. Pharm.. Des. 2010, 16, 3903-3920. [CrossRef]

24. Kolbe, M.; Xiang, Z.; Dohle, E.; Tonak, M.; Kirkpatrick, C.J.; Fuchs, S. Paracrine effects influenced by cell culture medium and consequences on microvessel-like structures in cocultures of mesenchymal stem cells and outgrowth endothelial cells. Tissue Eng. Part A 2011, 17, 2199-2212. [CrossRef] [PubMed]

25. Shi, Y.; Kramer, G.; Schröder, A.; Kirkpatrick, C.J.; Seekamp, A.; Schmidt, H.; Fuchs, S. Early endothelial progenitor cells as a source of myeloid cells to improve the pre-vascularisation of bone constructs. Eur. Cell Mater. 2014, 27, 64-79. [CrossRef]

26. Leal, D.; Mansilla, A.; Matsuhiro, B.; Moncada-Basualto, M.; Lapier, M.; Maya, J.D.; Olea-Azar, C.; De Borggraeve, W.M. Chemical structure and biological properties of sulfated fucan from the sequential extraction of subAntarctic Lessonia sp (Phaeophyceae). Carbohydr. Polym. 2018, 199, 304-313. [CrossRef] [PubMed]

27. Lahrsen, E.; Schoenfeld, A.K.; Alban, S. Size-dependent pharmacological activities of differently degraded fucoidan fractions from Fucus vesiculosus. Carbohydr. Polym. 2018, 189, 162-168. [CrossRef] [PubMed]

28. Lahrsen, E.; Schoenfeld, A.K.; Alban, S. Degradation of Eight Sulfated Polysaccharides Extracted from Red and Brown Algae and Its Impact on Structure and Pharmacological Activities. ACS Biomater. Sci. Eng. 2019, 5, 1200-1214. [CrossRef] [PubMed]

29. Ale, M.T.; Mikkelsen, J.D.; Meyer, A.S. Designed optimization of a single-step extraction of fucose-containing sulfated polysaccharides from Sargassum sp. J. Appl. Phycol. 2012, 24, 715-723. [CrossRef] 
30. Liu, J.; Wu, S.Y.; Chen, L.; Li, Q.J.; Shen, Y.Z.; Jin, L.; Zhang, X.; Chen, P.C.; Wu, M.J.; Choi, J.I.; et al. Different extraction methods bring about distinct physicochemical properties and antioxidant activities of Sargassum fusiforme fucoidans. Int. J. Biol. Macromol. 2020, 155, 1385-1392. [CrossRef] [PubMed]

31. Bittkau, K.S.; Neupane, S.; Alban, S. Initial evaluation of six different brown algae species as source for crude bioactive fucoidans. Algal Res. 2020, 45, 101759. [CrossRef]

32. Reijers, J.A.A.; Malone, K.E.; Bajramovic, J.J.; Verbeek, R.; Burggraaf, J.; Moerland, M. Adverse immunostimulation caused by impurities: The dark side of biopharmaceuticals. Br. J. Clin. Pharmacol. 2019, 85, 1418-1426. [CrossRef]

33. Burrell, R. Human responses to bacterial endotoxin. Circ. Shock 1994, 43, 137-153. [PubMed]

34. Janga, H.; Cassidy, L.; Wang, F.; Spengler, D.; Oestern-Fitschen, S.; Krause, M.F.; Seekamp, A.; Tholey, A.; Fuchs, S. Site-specific and endothelial-mediated dysfunction of the alveolar-capillary barrier in response to lipopolysaccharides. J. Cell Mol. Med. 2018, 22, 982-998. [CrossRef]

35. Ying, L.; Alvira, C.M.; Cornfield, D.N. Developmental differences in focal adhesion kinase expression modulate pulmonary endothelial barrier function in response to inflammation. Am. J. Physiol. Lung Cell Mol. Physiol. 2018, 315, L66-L77. [CrossRef] [PubMed]

36. Dalal, P.J.; Muller, W.A.; Sullivan, D.P. Endothelial Cell Calcium Signaling during Barrier Function and Inflammation. Am. J. Pathol. 2020, 190, 535-542. [CrossRef]

37. Grosso, A.; Burger, M.G.; Lunger, A.; Schaefer, D.J.; Banfi, A.; Di Maggio, N. It Takes Two to Tango: Coupling of Angiogenesis and Osteogenesis for Bone Regeneration. Front. Bioeng. Biotechnol. 2017, 5, 68. [CrossRef]

38. Midy, V.; Plouet, J. Vasculotropin/vascular endothelial growth factor induces differentiation in cultured osteoblasts. Biochem. Biophys. Res. Commun. 1994, 199, 380-386. [CrossRef] [PubMed]

39. Deckers, M.M.; Karperien, M.; van der Bent, C.; Yamashita, T.; Papapoulos, S.E.; Lowik, C.W. Expression of vascular endothelial growth factors and their receptors during osteoblast differentiation. Endocrinology 2000, 141, 1667-1674. [CrossRef]

40. Boisson-Vidal, C.; Zemani, F.; Caligiuri, G.; Galy-Fauroux, I.; Colliec-Jouault, S.; Helley, D.; Fischer, A.M. Neoangiogenesis induced by progenitor endothelial cells: Effect of fucoidan from marine algae. Cardiovasc. Hematol. Agents Med. Chem. 2007, 5 , 67-77. [CrossRef]

41. Dithmer, M.; Fuchs, S.; Shi, Y.; Schmidt, H.; Richert, E.; Roider, J.; Klettner, A. Fucoidan reduces secretion and expression of vascular endothelial growth factor in the retinal pigment epithelium and reduces angiogenesis in vitro. PLoS ONE 2014, 9, e89150. [CrossRef]

42. Ustyuzhanina, N.E.; Bilan, M.I.; Ushakova, N.A.; Usov, A.I.; Kiselevskiy, M.V.; Nifantiev, N.E. Fucoidans: Pro- or antiangiogenic agents? Glycobiology 2014, 24, 1265-1274. [CrossRef]

43. Hakanpaa, L.; Sipila, T.; Leppanen, V.M.; Gautam, P.; Nurmi, H.; Jacquemet, G.; Eklund, L.; Ivaska, J.; Alitalo, K.; Saharinen, P. Endothelial destabilization by angiopoietin-2 via integrin beta1 activation. Nat. Commun. 2015, 6, 5962. [CrossRef]

44. Tait, C.R.; Jones, P.F. Angiopoietins in tumours: The angiogenic switch. J. Pathol. 2004, 204, 1-10. [CrossRef] [PubMed]

45. Eman, R.M.; Öner, F.C.; Kruyt, M.C.; Dhert, W.J.A.; Alblas, J. Stromal Cell-Derived Factor-1 Stimulates Cell Recruitment, Vascularization and Osteogenic Differentiation. Tissue Eng. Part A 2013, 20, 466-473. [CrossRef] [PubMed]

46. Salcedo, R.; Oppenheim, J.J. Role of chemokines in angiogenesis: CXCL12/SDF-1 and CXCR4 interaction, a key regulator of endothelial cell responses. Microcirculation 2003, 10, 359-370. [CrossRef] [PubMed]

47. Yu, D.; Lv, F.; Zhang, J.; Li, H. SDF-1 Expression is Associated with Poor Prognosis in Osteosarcoma. Ann. Clin. Lab. Sci. 2016, 46, 508-514.

48. Benslimane-Ahmim, Z.; Pereira, J.; Lokajczyk, A.; Dizier, B.; Galy-Fauroux, I.; Fischer, A.M.; Heymann, D.; Boisson-Vidal, C. Osteoprotegerin regulates cancer cell migration through SDF-1/CXCR4 axis and promotes tumour development by increasing neovascularization. Cancer Lett. 2017, 395, 11-19. [CrossRef] [PubMed]

49. Fuchs, S.; Hofmann, A.; Kirkpatrick, C. Microvessel-like structures from outgrowth endothelial cells from human peripheral blood in 2-dimensional and 3-dimensional co-cultures with osteoblastic lineage cells. Tissue Eng. 2007, 13, 2577-2588. [CrossRef]

50. Gupta, D.; Silva, M.; Radziun, K.; Martinez, D.C.; Hill, C.J.; Marshall, J.; Hearnden, V.; Puertas-Mejia, M.A.; Reilly, G.C. Fucoidan Inhibition of Osteosarcoma Cells Is Species and Molecular Weight Dependent. Mar. Drugs 2020, 18, 104. [CrossRef]

51. Ptak, S.H.; Christensen, K.V.; Meichßner, R.; Fretté, X. Improving fucoidan yield from fucus brown algae by microwave extraction. Chem. Eng. 2019, 74, 109-114.

52. Albersheim, P.; Nevins, D.J.; English, P.D.; Karr, A. A method for the analysis of sugars in plant cell-wall polysaccharides by gas-liquid chromatography. Carbohydr. Res. 1967, 5, 340-345. [CrossRef]

53. Fuchs, S.; Hermanns, M.I.; Kirkpatrick, C.J. Retention of a differentiated endothelial phenotype by outgrowth endothelial cells isolated from human peripheral blood and expanded in long-term cultures. Cell Tissue Res. 2006, 326, 79-92. [CrossRef] [PubMed]

54. Kolbe, M.; Dohle, E.; Katerla, D.; Kirkpatrick, C.J.; Fuchs, S. Enrichment of outgrowth endothelial cells in high and low colony-forming cultures from peripheral blood progenitors. Tissue Eng. Part C Methods 2010, 16, 877-886. [CrossRef] 